\title{
Neotectonics and glacial deformation in the Karakoram Mountains and Nanga Parbat Himalaya
}

\author{
LEWIS A. OWEN \\ Departments of Geography and Geology, University of Leicester, Leicester LE1 7RH (Great Britain) \\ (Received December 1, 1987; accepted May 8, 1988)
}

\begin{abstract}
Owen, L.A. 1989. Neotectonics and deformation in the Karakoram Mountains and Nanga Parbat Himalaya. In: N.-A. Mörner and J. Adams (Editors), Paleoseismicity and Neotectonics. Tectonophysics, 163: 227-265.

The Karakoram Mountains and the Nanga Parbat Himalaya are one of the most rapidly rising mountain areas in the world with uplift rates in the order of $2 \mathrm{~mm} / \mathrm{yr}$. Large-scale regional warping is the most likely form of uplift with the greatest rates around the Nanga Parbat-Haramosh Massif. Only two active faults have been recognised in the Pakistan Karakoram, the Rakhiot and the Misgar valley fault. The Rakhiot fault zone is a neotectonic expression of the rapid uplift centred around the Nanga Parbat syntaxis. Deformation structures in Quaternary and Recent sediments in the Rakhiot area are not produced solely by neotectonic processes but also by processes in the glacial depostional environment and slope related processes. Structures present vary from neotectonic shear zones, folds, thrusts and high-angled faults; glacially produced folds, thrusts, shears and joints; and debris slides bounded by discrete shear zones.
\end{abstract}

The distinction between these structures is vital in making valid neotectonic models for high active mountain belts.

\section{Introduction}

The Trans-Himalayan mountain belt, separating the Indian and Asian plates is one of the youngest and most rapidly rising mountain systems in the world. The Karakoram Mountains * and the Nanga Parbat Himalaya (Great Himalaya) are situated at the western end of the TransHimalayan mountain belt bordering the northwestern margin of the Himalayas and connecting the Hindu Kush and Pamir Mountains (Fig. 1).

It has been advocated by many authors that the uplift of the Himalayas and Karakoram has occurred during recent geological time especially

\footnotetext{
* In this study the Kohistan area comprising rocks of the Kohistan island are sequence (Coward et al., 1982b) are included as part of the Karakoram Mountains.
}

during Quaternary and Holocene times (Wadia, 1979; Zeitler, 1985; Coward et al., 1987). Table 1 gives estimates of uplift rates for selected areas in the Himalayas. This suggests an average uplift in excess of $2 \mathrm{~mm} / \mathrm{yr}$ for the whole of the Karakoram Mountains.

Within the Karakoram and Nanga Parbat region the Quaternary sedimentary record is well preserved in a series of small interconnecting basins, frequently with valley fills in excess of 500 $\mathrm{m}$ thick. These comprise, debris-flow, tills, fluvial, glaciofluvial and lacustrine sediments. Many of these have been deformed and locally river terraces have been thrusted, folded and inverted. In such an active tectonic environment a tectonic origin for these structures is often invoked. However, other processes may produce structures similar to neotectonic structures such as processes in 


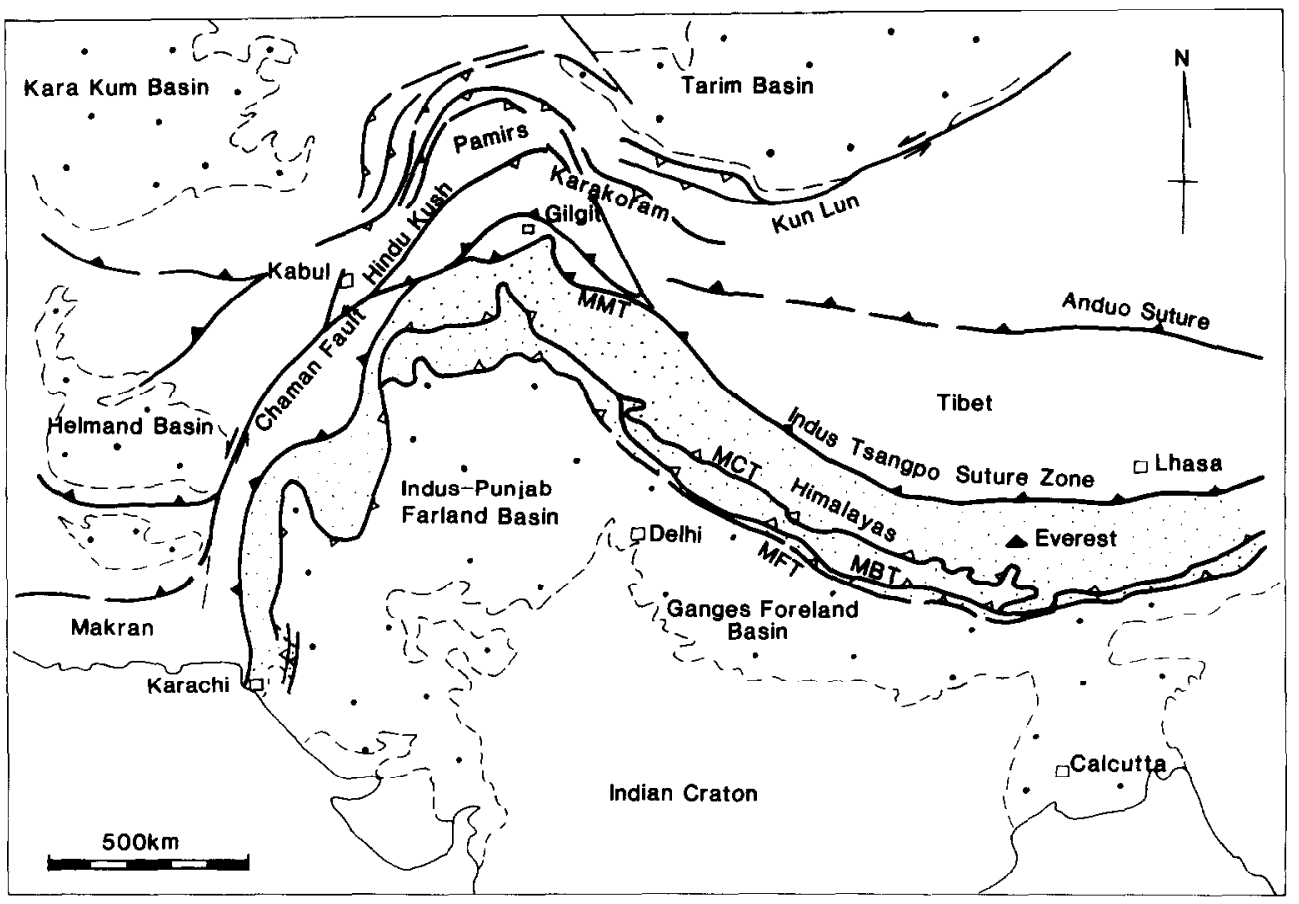

Fig. 1. Main sutures and Quaternary basins in the Himalayan arc.

the glacial depositional environment, debris-flow and the sliding of sediments down palaeoslopes (Owen, 1987).

Only two active faults have been recognised in the Pakistan Karakoram and Nanga Parbat Himalaya, the Rakhiot fault (Lawrence and Shroder, 1984) and a recently discovered fault in the politically restricted Misgar Valley (Gorzanti, pers. commun., 1987) northwest of Sost (Fig. 2). The aim of this paper is to discuss the neotectonic framework for the Pakistan Karakoram and Nanga Parbat Himalaya and to describe the deformation structures present within the Quaternary sedimentary sequence to help shed light on the interaction between neotectonics and glacial depositional processes in high active mountain belts. The area

\section{TABLE 1}

Uplift rates in the Himalayas

\begin{tabular}{cll}
\hline $\begin{array}{l}\text { Uplift rates } \\
(\mathrm{mm} / \mathrm{yr})\end{array}$ & Method of determination & Source \\
\hline $0.1-4.5$ & Fission-track dating (northern Pakistan) & Zeitler (1985) \\
$0.7-0.8$ & Mincral cooling temperatures (High Himalaya) & Mehta (1980) \\
2.0 & Growth of sub-marine fans (Bengal fan) & Curray and Moore (1971) \\
$1.0-1.3$ & River profiles (northern Pakistan) & Gornitz and Seeber (1981) \\
$5-12$ & Flexual modelling of the lithosphere (northern Pakistan) & Seeber and Gornitz (1981) \\
& & Lyon-Caen and Molnar (1983) \\
1.8 & Sediment load in rivers (Karakoram) & Ferguson (1984) \\
1 & River terraces (Nepal) & Iwata et al. (1984) \\
$1.2-1.5$ & Levelling of river terraces (Nepal) & Iwata (1987) \\
$>0.65$ & Erosion and sediment yield (Annapurna Range, Nepal) & Fort (1987) \\
\hline
\end{tabular}




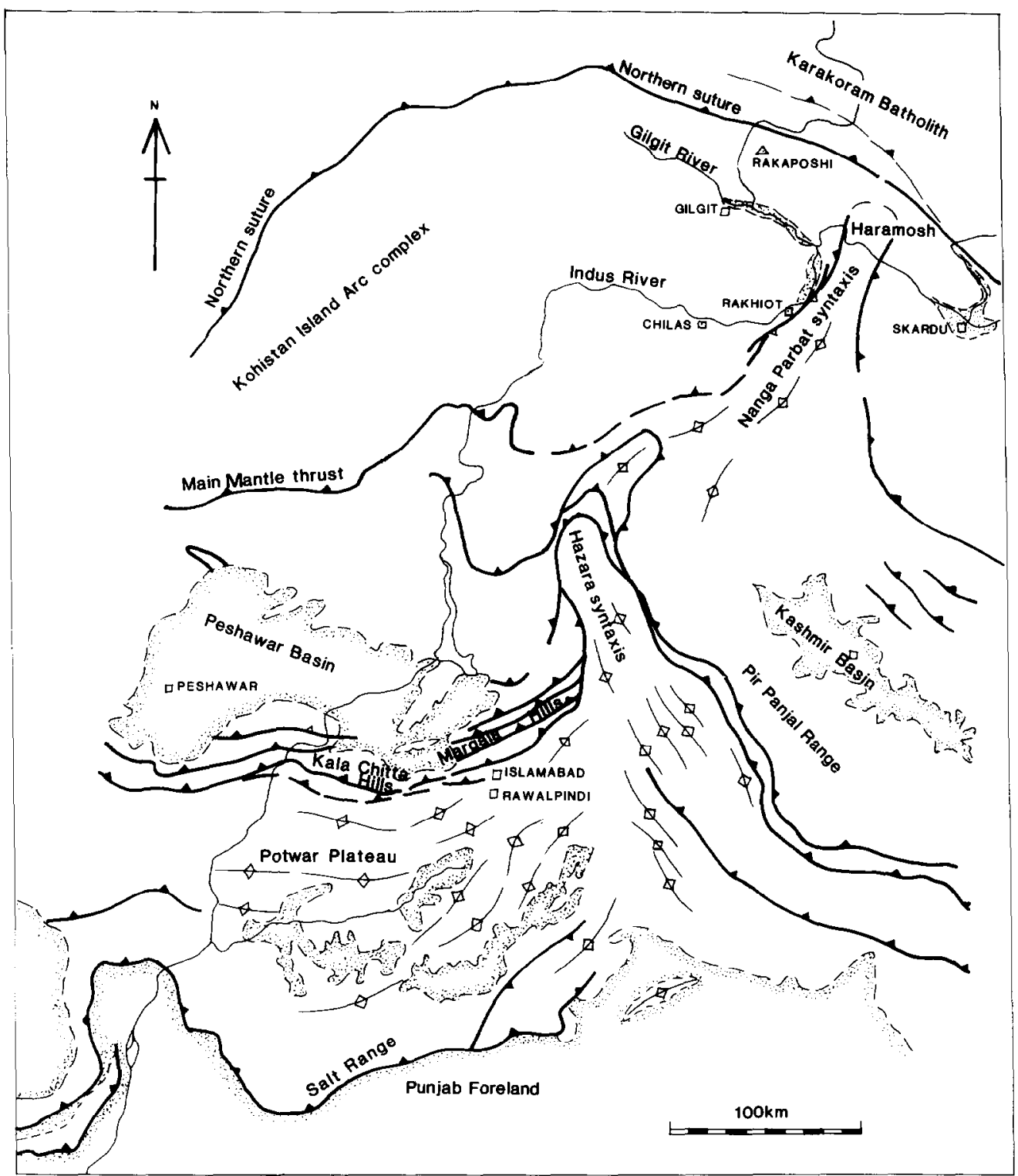

Fig. 2. Geological structures and Quaternary basins in the western Himalaya and Karakoram.

around the Rakhiot fault in the middle Indus valley is used to serve as a case study (Fig. 3).

\section{Geological setting}

The Indus-Tsangpo suture zone represents the junction between the collision of the Indian and Asian continental plates in the Central Himalayas (Gansser, 1980; Fig. 1). To the west, in the Karakoram and Great Himalaya, this suture zone bifurcates into the Main Mantle thrust (MMT) to the south and the northern suture to the north
(Coward et al., 1982b) enclosing the Kohistan island arc complex, which comprises basic to in termediate volcanic rocks, volcaniclastic sediments, limestones, medium-grained basic intrusives; and granites, tonalite and diorite intrusions of Cretaceous age (Petterson and Windley, 1985; Coward et al., 1987). These rocks have been obducted onto Neogene metamorphic Indian crustal basement and the island arc has been effectively rotated so that its deepest levels are exposed to the south. It has been folded into several large southward facing folds, no major faults have been 


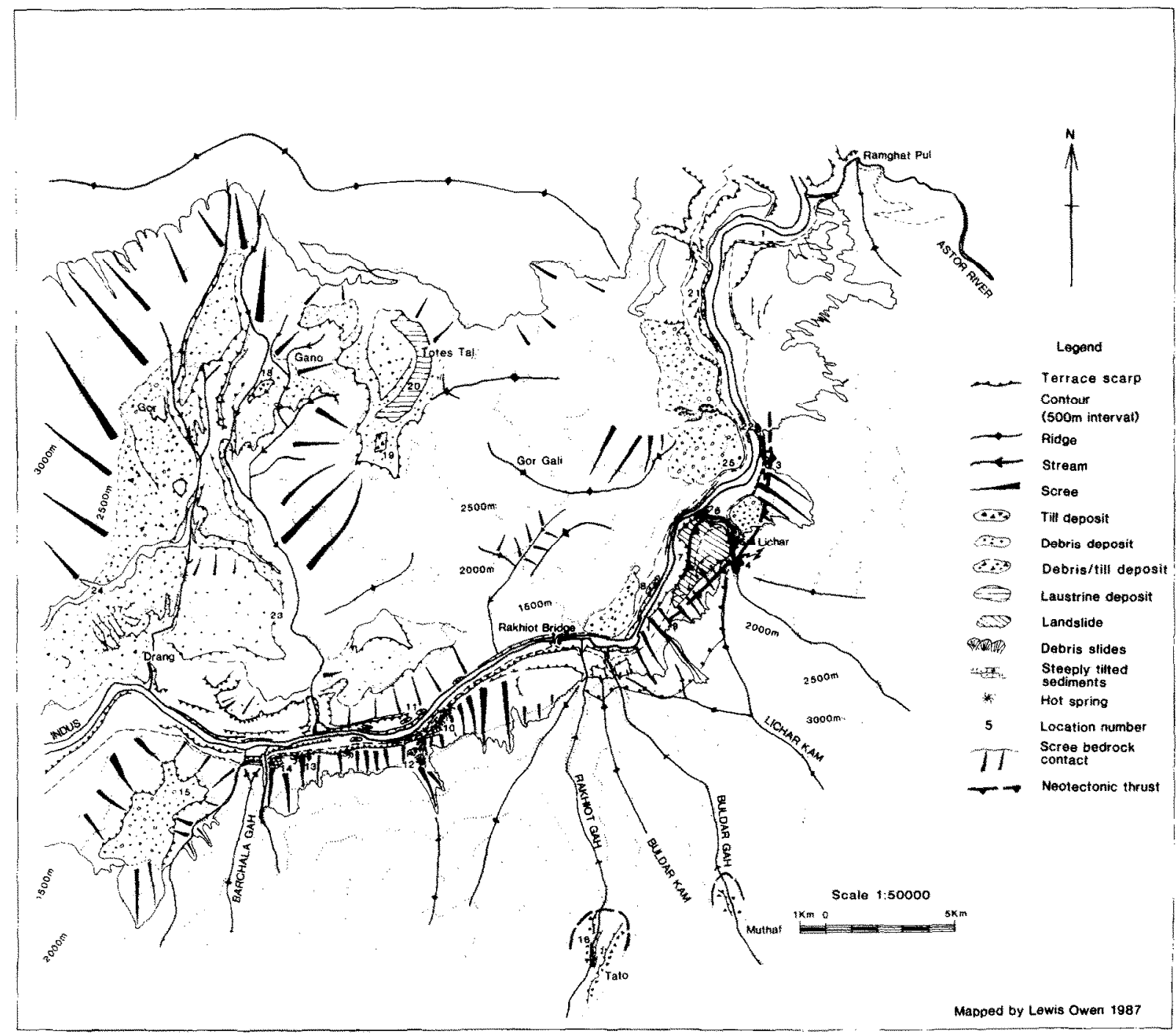

Fig. 3. Neotectonic and geomorphic map of the Rakhiot area.

mapped within the complex. The MMT represents the suture between the Kohistan complex and the Indian plate (Tahinkheli and Jan, 1979); this forms a tight loop around the Nanga Parbat-Haramosh Massif, the "Nanga Parbat syntaxis". The MMT is offset by the Rakhiot fault zone which has been traced along the Indus valley from Buna Gah to the Khalter valley, northwest of Haramosh (Lawrence and Shroder, 1984; Butler and Prior, 1988). This comprises a zone of faults, fault rocks and mylonites (Butler and Prior, 1988), some of which have deformed Quaternary sediments.

The northern suture comprises a tectonic mélange containing imbricated lenses of Kohistan volcanics and sediments mixed with basic to ultrabasic rocks, turbiditic sandstones, and slates of the adjacent Asian plate (Coward et al., 1986). North of the northern suture Asian plate rocks comprise sandstones, slates and limestones of basin and shelf facies overthrust by the Karakoram Batholith along the Hunza shear. No active faults have been recognised along the northern suture, but a series of hot springs are present at Chalt and Ishkumen near the northern suture and these may be related to this suture. A major valley lineation, the Shigar, trends parallel to the suture in Bal- 
tistan and in 1980 a microseismic earthquake was recorded along this valley (Khurshid et al., 1984). However, there is no evidence of neotectonic faulting in the Quaternary and Holocene sediments of the Shigar valley to support the presence of an active fault.

Estimates of uplift rates using fission-track methods (Zeitler, 1985) imply movements in excess of $0.7 \mathrm{~cm} / \mathrm{yr}$ in the Nanga Parbat-Haramosh Massif. These rates decline in magnitude away from Nanga-Parbat and in the Kohistan island arc complex more modest estimates of $0.1 \mathrm{~cm} /$ year have been calculated (Zeitler, 1985). The increased uplifts around Nanga Parbat-Haramosh area represents the culmination of Nanga Parbat gneiss, the Rakhiot fault being a function of the recent uplifts.

\section{Seismicity}

The Karakoram-Nanga Parbat area is seismically active. Figure 4 shows the areas of recorded earthquakes during the last decade based on portable seismic networks. This shows the existence of a major seismic zone in the area of Darel, Hamrun and Tangir valleys, indicating NNE-SSW compression (Fig. 4). Seismicity was confined to shallow levels $(<45 \mathrm{~km})$ within the crust. Other shallow events were also recorded in Baltistan and may have been related to lineaments along the Shigar, Hushe and Shyok valleys. No neotectonic structures have been recognised in these valleys but, the Tangir, Hamrun and Tangir areas are lacking in field study. Khurshid's et al. (1984) portable seismic network confirmed another seismic zone of intermediate-depth, the IndoKohistan seismic zone (IKSZ; Ambruster et al., 1978) to the south of the Karakoram which was interpreted as an extension of the Himalayan basement thrust, but any neotectonic surface expressions of this zone, such as faulting, have not been recognised.

\section{Lineaments, drainage and Quaternary basins}

An orthogonal pattern of lineaments can be recognised throughout the Karakoram using Landsat imagery which may relate to neotectonic structures. These may be valley lineaments, bedrock lineaments or extraordinary linear glaciers. Some of the drainage patterns are unusual, e.g., tributary streams often form acute angles facing

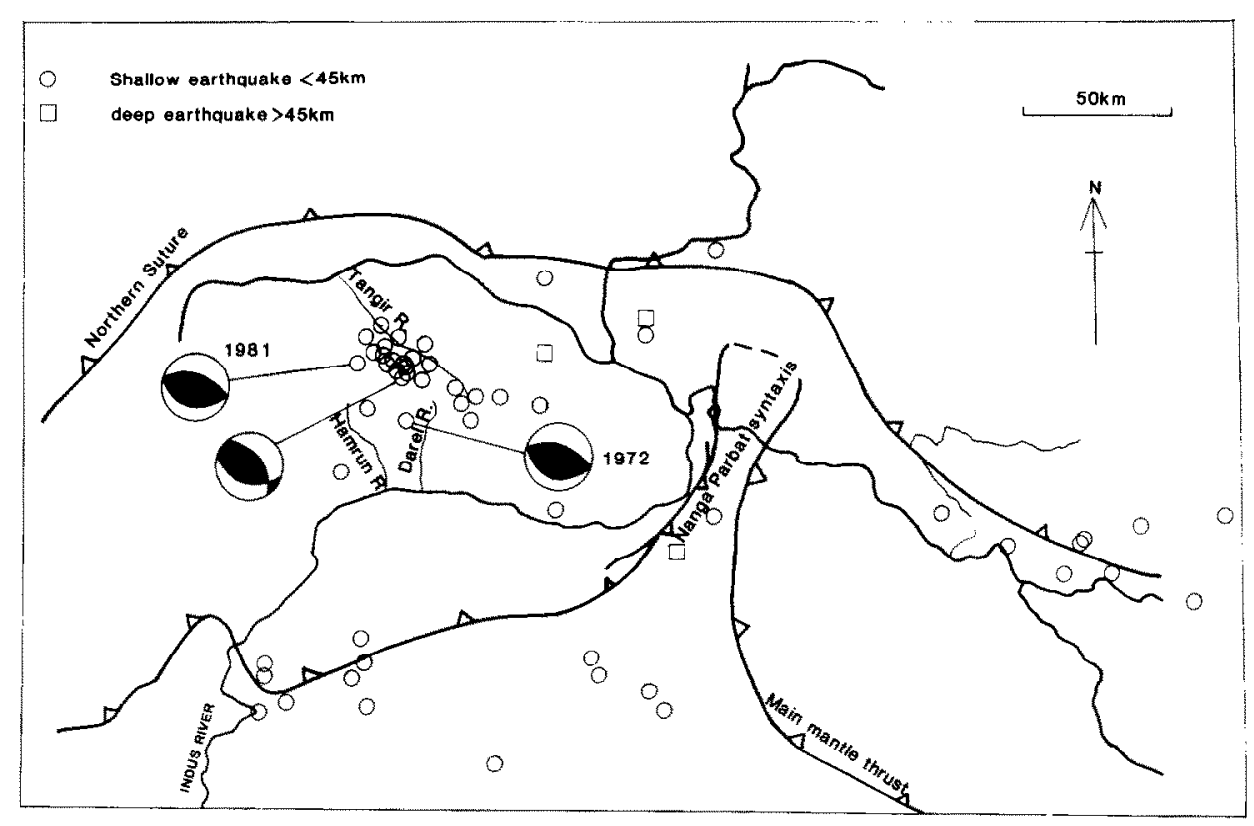

Fig. 4. Map of recorded seismic events in the Kohistan area after Yielding et al. (1984), Gornitz and Seeber (1981) and Kurshid et al. (1984). 


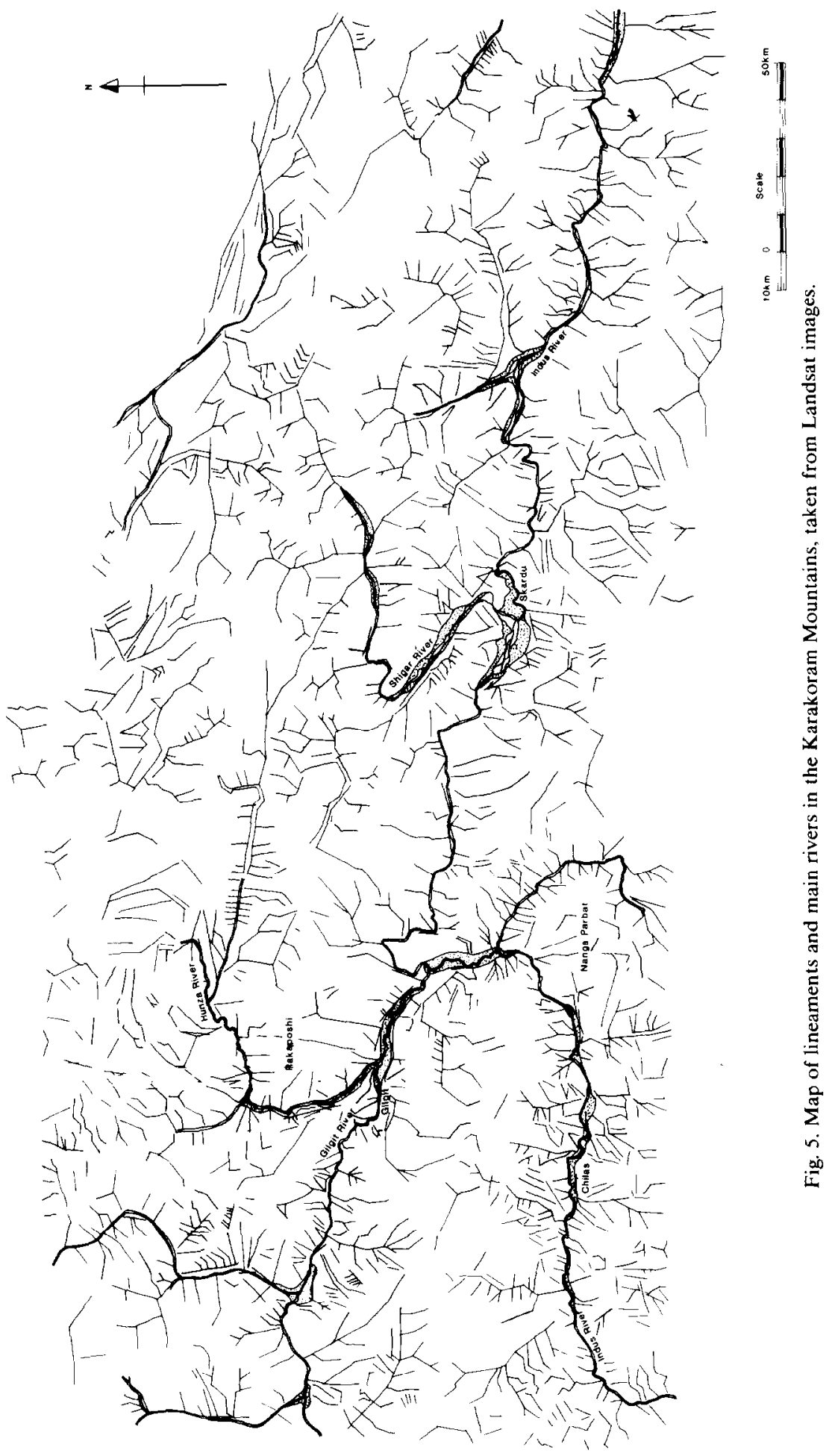




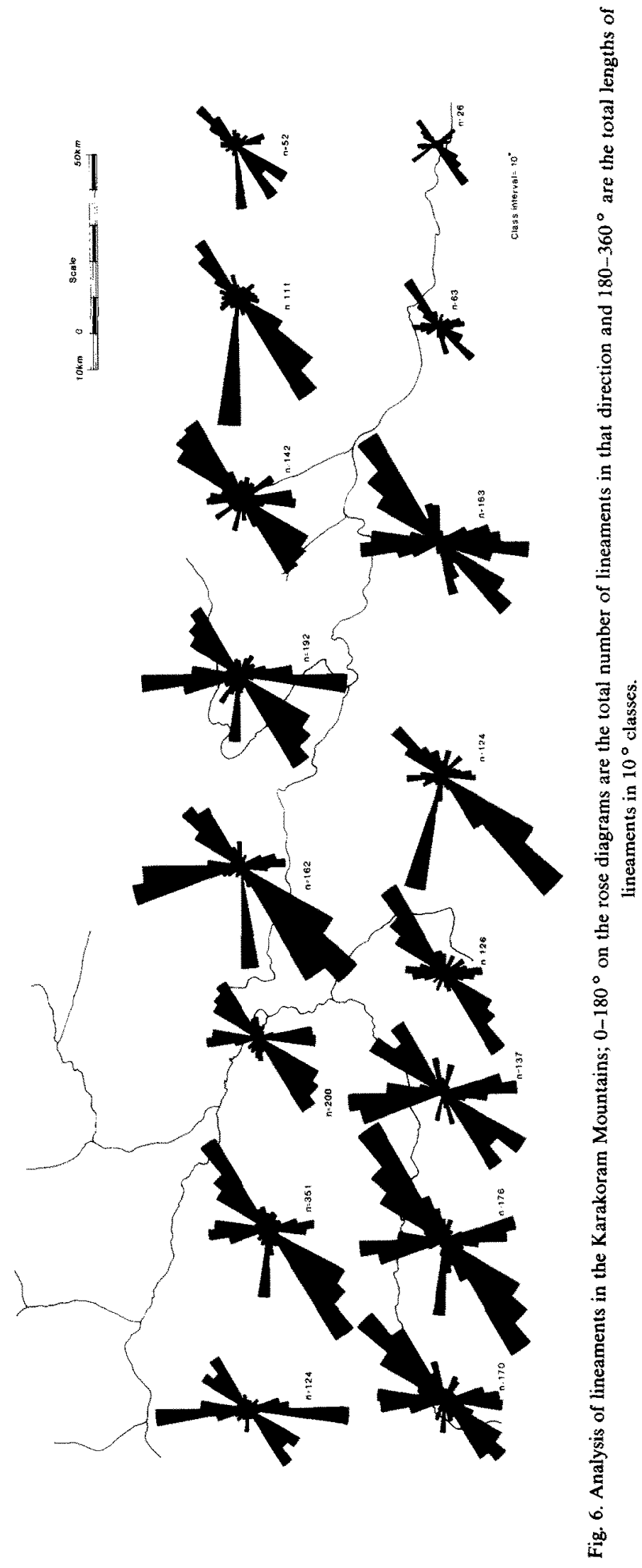


upstream with the main river, rather than downstream as is usual. Lineaments common to two or more Landsat passes were plotted on a base map and rose diagrams were constructed showing the number and total length of lineaments in ten degree intervals (Figs. 5 and 6). Two main sets were recognised, a NNW-SSE set and a SW-NE set. There was no systematic variation across the Karakoram.

Coward et al. (1987) emphasised the arcuate trend of thrusts and fanning transport directions throughout the Himalayas. In the foreland thrust belt of northern Pakistan thrust transport directions verge toward the southeast and in Kashmir they verge toward the southwest. Coward et al. (1987) suggest that in order to accommodate the major crustal anticlines of the Nanga Parbat syntaxis and the Hazara syntaxis (Fig. 2), it is necessary to have gravity spreading producing extensional faults in the hinterland as are present in China and Tibet (Tapponnier et al., 1981) and in the Greater Himalaya near Everest (Burg and Chen, 1984). If this was the case in Pakistan, extensional faults should trend ENE and SSE in the Karakoram west of the Nanga Parbat syntaxis. These have not been recognised and the results of the lineament analysis does not fit this model.

An alternate model was proposed by Tapponnier and Molnar (1976) using slip-line field theory. They considered the collision between the Indian plate to be a rigid indenture into the Asian plate focussed on the western Himalayas. This model predicts two sets of ESE and NNW trending strike-slip faults in westernmost Pakistan and two sets of ESE and NNE trending strike-slip faults in northeastern Pakistan. Again the orientation of the lineaments in the Pakistan Karakoram do not conform to this model.

It is striking that the E-W trend of the Indus is deflected around the Nanga Parbat syntaxis and that the Indus parallels the Great Himalaya for several hundred kilometres from Ladakh. This indicates that the Indus river course is younger than the uplift of the Great Himalaya. However, it is apparent from the analysis of the lineaments, that the dominant NNW set of lineaments trend against the grain of the Karakoram. The Shigar, Hushe, Khapalu, Ishkumen, Yasin and Hunza rivers, as well as minor rivers, all show discordant drainage. This may relate to a primeval drainage system.

It is therefore suggested that these NNW-SSE and SW-NE lineaments plus the pronounced discordant drainage were controlled by an old structure which developed early in the history of the Karakoram Mountains. The trend of these lineaments may be controlled by a major joint system which produced a weakness, which a primeval drainage exploited, although no major faults developed. It is noted that the lineations trend NNW and NE and are in the correct orientation for joints that would develop on major folds that trended ESE. This would be expected in eastern Kohistan with such folds as the Jaglot syncline (Coward et al., 1982b), which has a mapped axial trace trending ESE. Scheidegger and Ai (1986) have shown similar relationships between the geomorphology and structure for the Lenglongling Range in the eastern part of the Quilian mountains, northern Tibet. The Nanga Parbat syntaxis developed later producing rapid uplift and active structures such as the Lichar thrust. Consequently the uplift of the Nanga-Parbat massif and the Great Himalaya modified the Indus drainage which now flows parallel to the trend of the Great Himalaya and its drainage is deflected around the Nanga Parbat-Haramosh massif.

The Quaternary basins in the Karakoram and Nanga Parbat area comprise a series of beaded basins interconnected by the major rivers which generally occur at the confluence of two rivers e.g., Skardu basin, the Shigar and Indus rivers; Gilgit basin, the Gilgit and Hunza rivers. There is no evidence that they are structurally controlled and no faults have been mapped. These basins comprise vast thicknesses of glacial, glaciofluvial, fluvial and debris-flow sediments showing repeated cycles of glacial and river denudation which enlarged the confluence producing basins and depositing sediments to produce thick valley fills.

\section{Quaternary and recent structures in the Rakhiot area}

The complex interaction between glacial processes, sedimentation and neotectonics is well 
displayed in the middle Indus valley around Rakhiot (Fig. 3). Few examples of the style of structures produced in sediments by neotectonic processes have been described in detail. These examples will help shed light on the nature of this type of deformation.

\section{Lichar thrust}

At Lichar Gah a major neotectonic thrust is exposed emplacing Precambrian high-grade metamorphic Nanga Parbat gneiss over unlithified glaciofluvial sediments (Fig. 7). The thrust is exposed between screes for 2 miles south of Lichar, where the footwall rocks cease to be glaciofluvial sediments and are present as Nanga Parbat gneiss. Northwards the thrust's outcrop can be traced for $2.5 \mathrm{~km}$, but extensive scree cover makes it impossible to map it farther north (Fig. 3). This thrust is part of the Rakhiot fault zone mapped by Lawrence and Shroder (1985), from Bunar Gah to the Khaltar valley. Their Rakhiot fault is a zone of faults (Butler and Prior, 1988) of which the Lichar thrust is a neotectonic expression.

The hangingwall rocks are complexly deformed by thrusts which parallel the Lichar thrust (Fig. 8). The Lichar thrust has a minimum displacement of $300 \mathrm{~m}$. The footwall rocks at Lichar Gah have been inverted beneath the thrust and comprise unlithified sands and gravels with grain size characteristics which are similar to other Karakoram glaciofluvial sands (Li Jijun et al., 1984; Owen, 1988b) (Fig. 9). However, they are better sorted and they probably represent distal outwash sediments related to the retreat of the main valley glaciation. This retreat would allow a larger transport distance for sorting to occur. These onlap tills and are overthrust by till at several locations throughout the valley.

The thrust comprises a 4-5 m zone of sheared and gouged gneiss and sands (Fig. 8). Five main zones can be distinguished from top to bottom:

(1) Sheared blocks of gneiss and small thrusts with micro-duplexes (approx. $1 \mathrm{~m}$ thick)

(2) Highly sheared gneiss (1-2 $\mathrm{m}$ thick)

(3) Sandy clay fault gouge of comminuted gneiss and glaciofluvial sands (5-15 cm thick)

(4) Discrete shears in glaciofluvial sands of the order of a metre in length (a zone of 2-4 m)

(5) Relatively undeformed glaciofluvial sands which have steep dipping conjugate joints.

Bedding is difficult to distinguish beneath the thrust but small pebbly channels demonstrate that the beds have been inverted and dip at $10-15^{\circ} \mathrm{ESE}$. These beds steepen down section and in the stream are upright, dipping $60-80^{\circ} \mathrm{NNW}$.

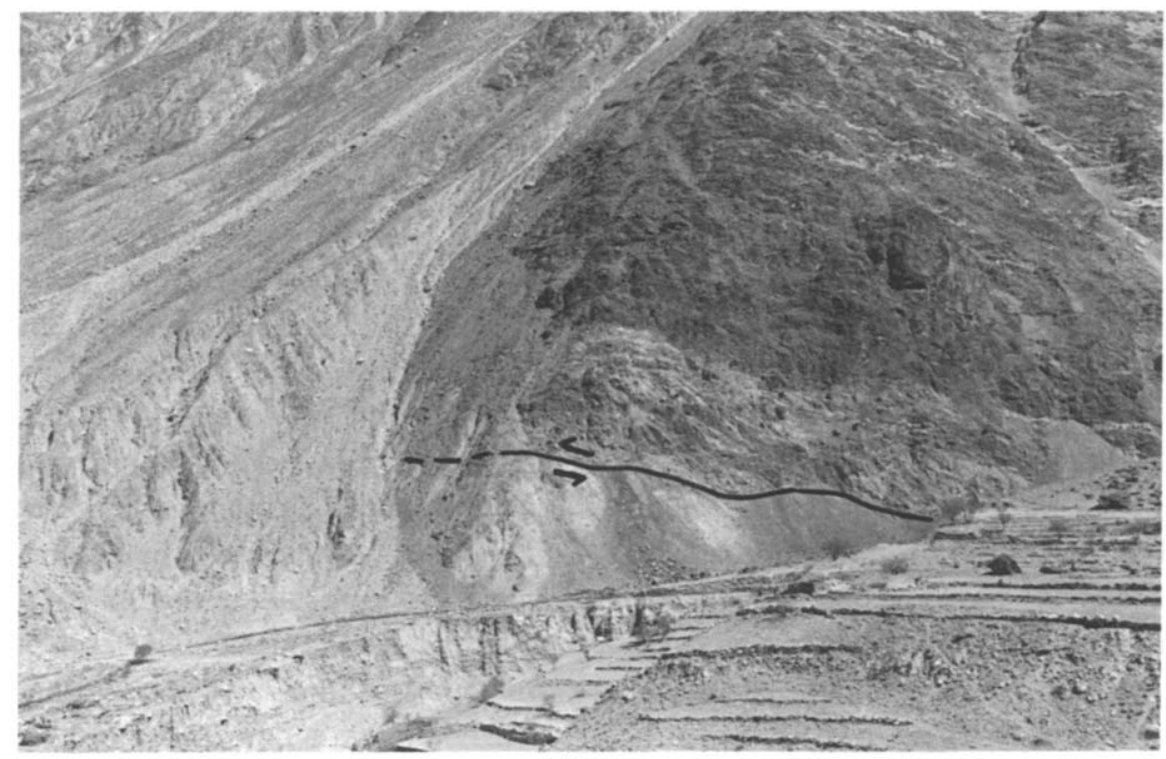

Fig. 7. Lichar Thrust at Lichar Gah, Nanga Parbat gneiss thrust over glaciofluvial sands. 


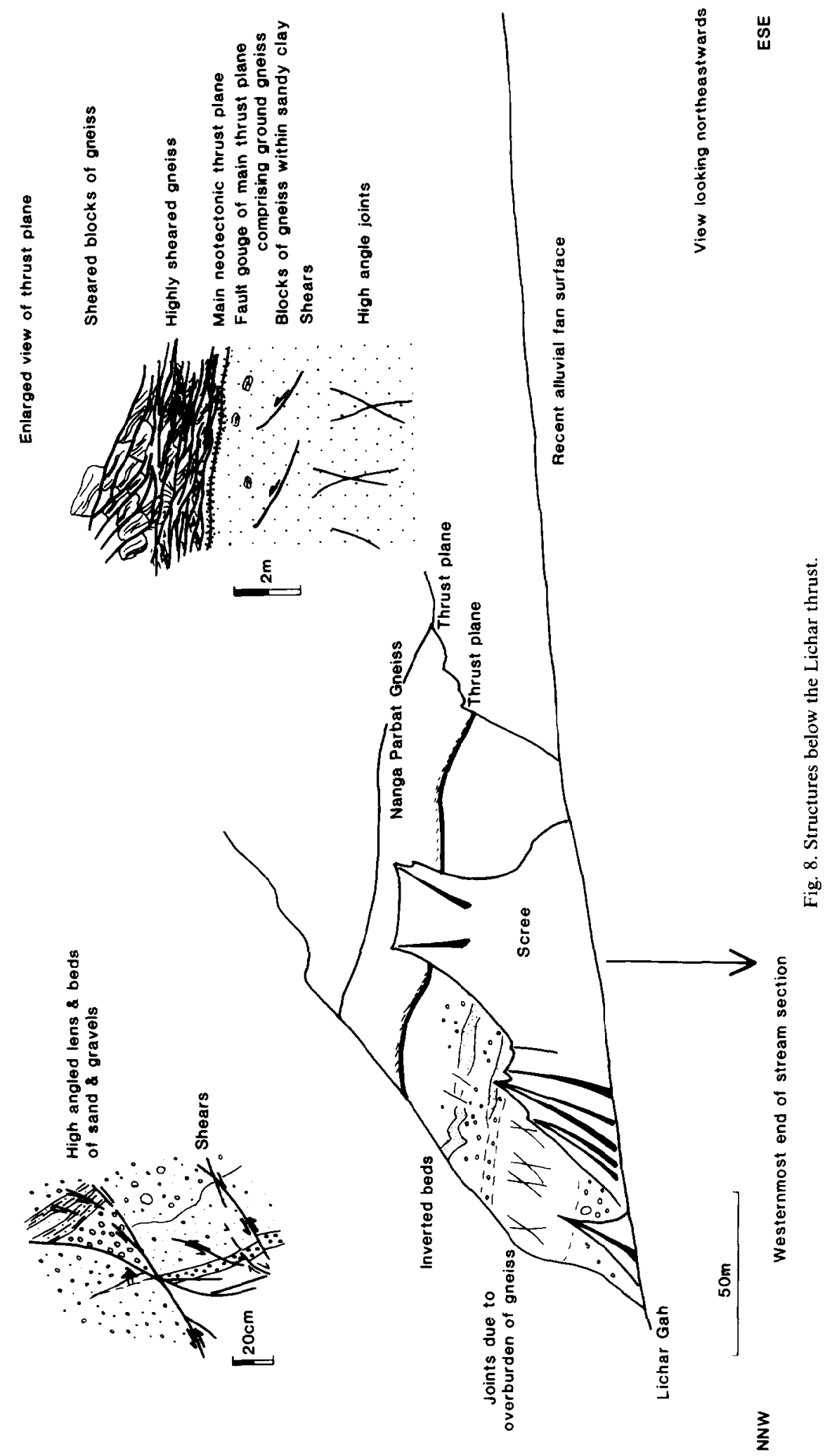




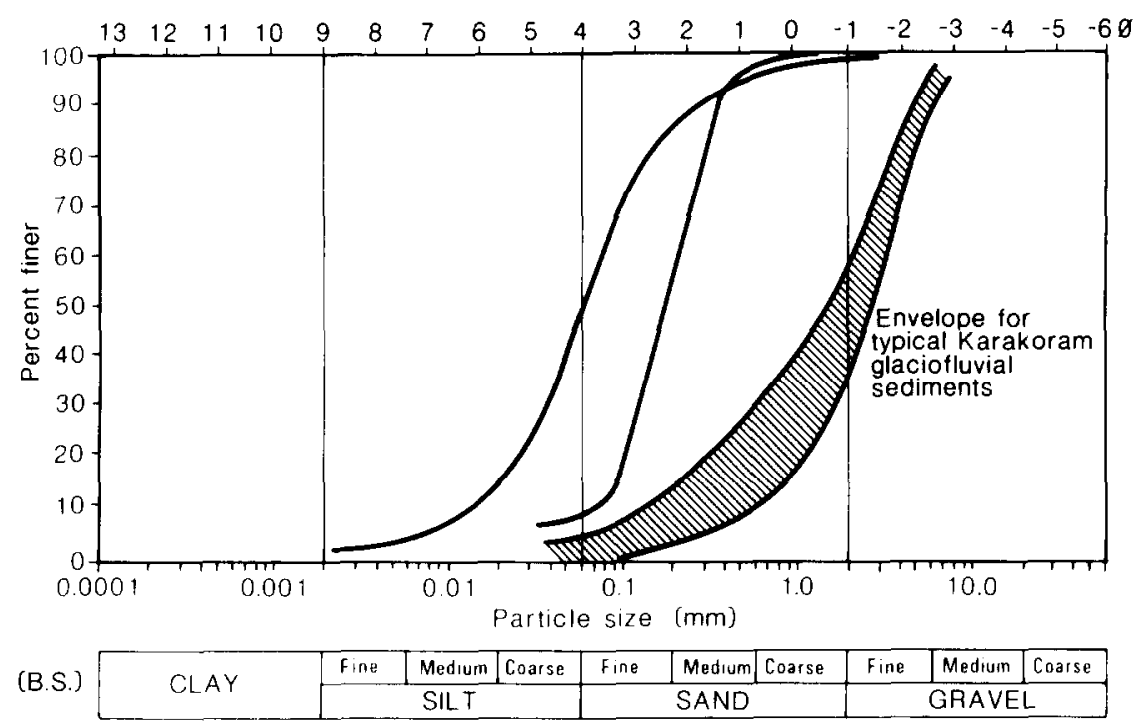

Fig. 9. Grain-size distribution of glaciofluvial sands beneath the Lichar Thrust and those of typical Karakorum fluvioglacial sands (Li Jijun et al., 1984).

The beds form limbs of a fold.

Faulting is present beneath the thrust zone as high-angle shears dipping NNW with a downward movement towards the north-northwest. In the stream section beneath the road at Lichar Gah the steeply dipping sands and gravels are pervasively sheared sub-parallel to the bedding (Fig. 10). Some become listric and micro-fabric studies using the scanning electron microscope support field evidence for NNW downward movement (Fig. 11). In the more competent sands well developed conjugate joints dip $60^{\circ} \mathrm{NNW}$ and SSE.

Clearly, several stages of development can be recognised (Fig. 12). Initially glaciofluvial sands and gravels were deposited in the Indus valley, probably inclined at a low angle towards the axis of the valley (Fig. 12B). Movement along the thrust emplaced Nanga Parbat gneiss over glaciofluvial sands and conglomerates and tilted the beds (Fig. 12C). Further movement eventually folded the sands inverting the upper limb (Fig. 12D, E). The base of the gneiss and the top of the sands were sheared and gouged into a relatively narrow zone. The immense thickness of Nanga Parbat gneiss at least $300-500 \mathrm{~m}$ above the sediments induced a lithostatic stress on the sediments producing high-angled joints and a major series of shears which are best seen in the stream bed at
Lichar Gah. These shears effectively moved blocks of sediment north-northwestwards from underneath the thrust. Alternatively these may be thrusts that have been propagated downwards from the Lichar thrust if it became pinned (Fig. 12F): this may be described as a surge zone.

\section{Lichar Spur landslide}

During late 1840 or early 1841 an earthquake initiated the collapse of the Lichar Spur which consequently blocked the Indus valley to a depth of $300 \mathrm{~m}$ (Drew, 1875). This produced a nearly 40 miles long lake which eventually reached the top of the blockage during late May. Early one day in June the blockage was bridged and the flood waters devastated a Sikh army that was camped on the Chach Plain near Attock, $400 \mathrm{~km}$ downstream (Shaw, 1871; Henderson, 1859; Obbard, 1860; Mason, 1929).

The remnants of this landslide can be observed immediately south of Lichar Village and cover an area approximately $4 \mathrm{~km}^{2}$ (Fig. 3). Fig. 12A shows the relationship between the present topography, the Lichar thrust, the Indus river and the Lichar landslide.

Most of the landslide comprises a complete section of the Lichar spur which rotated through 

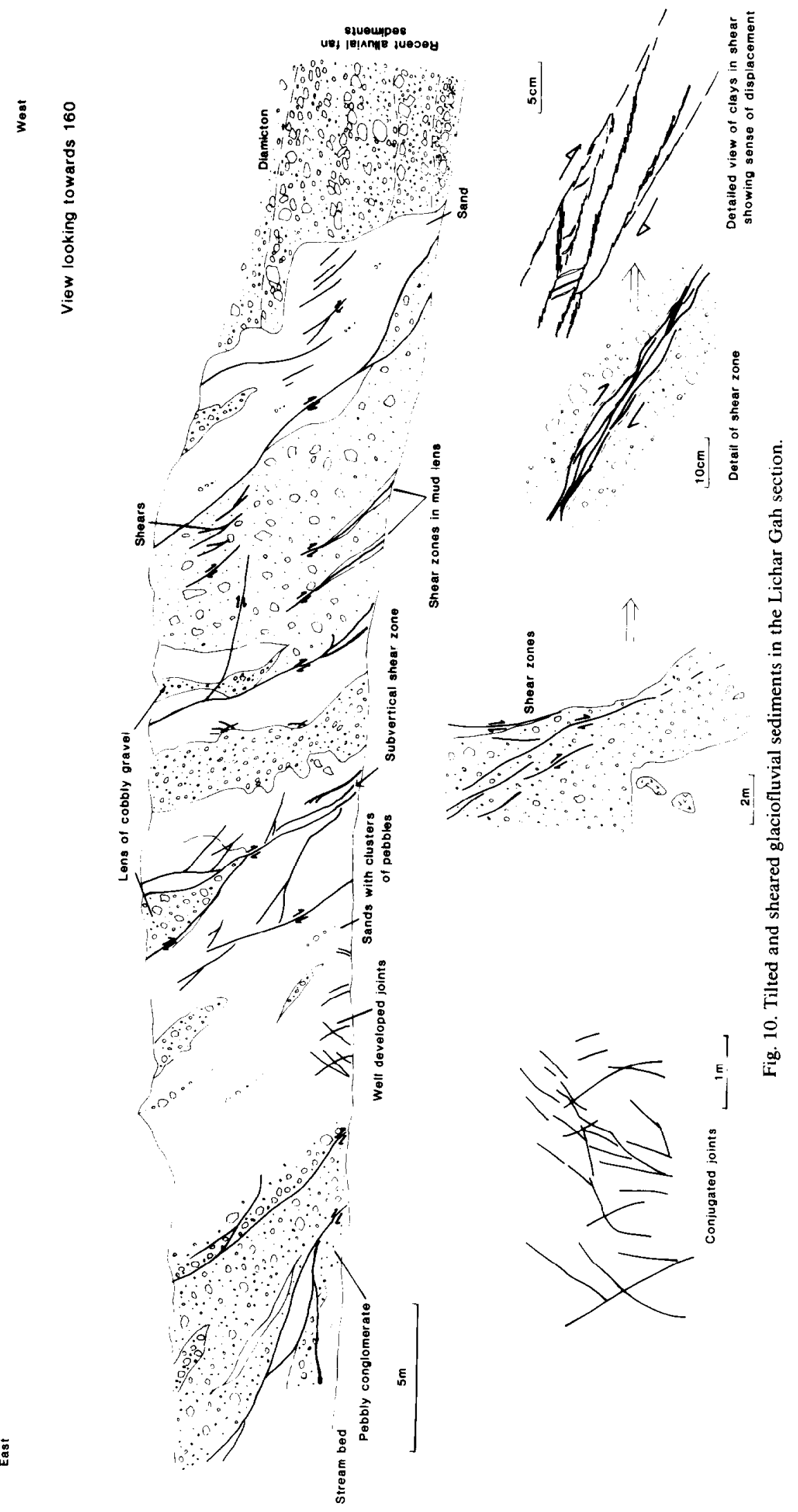

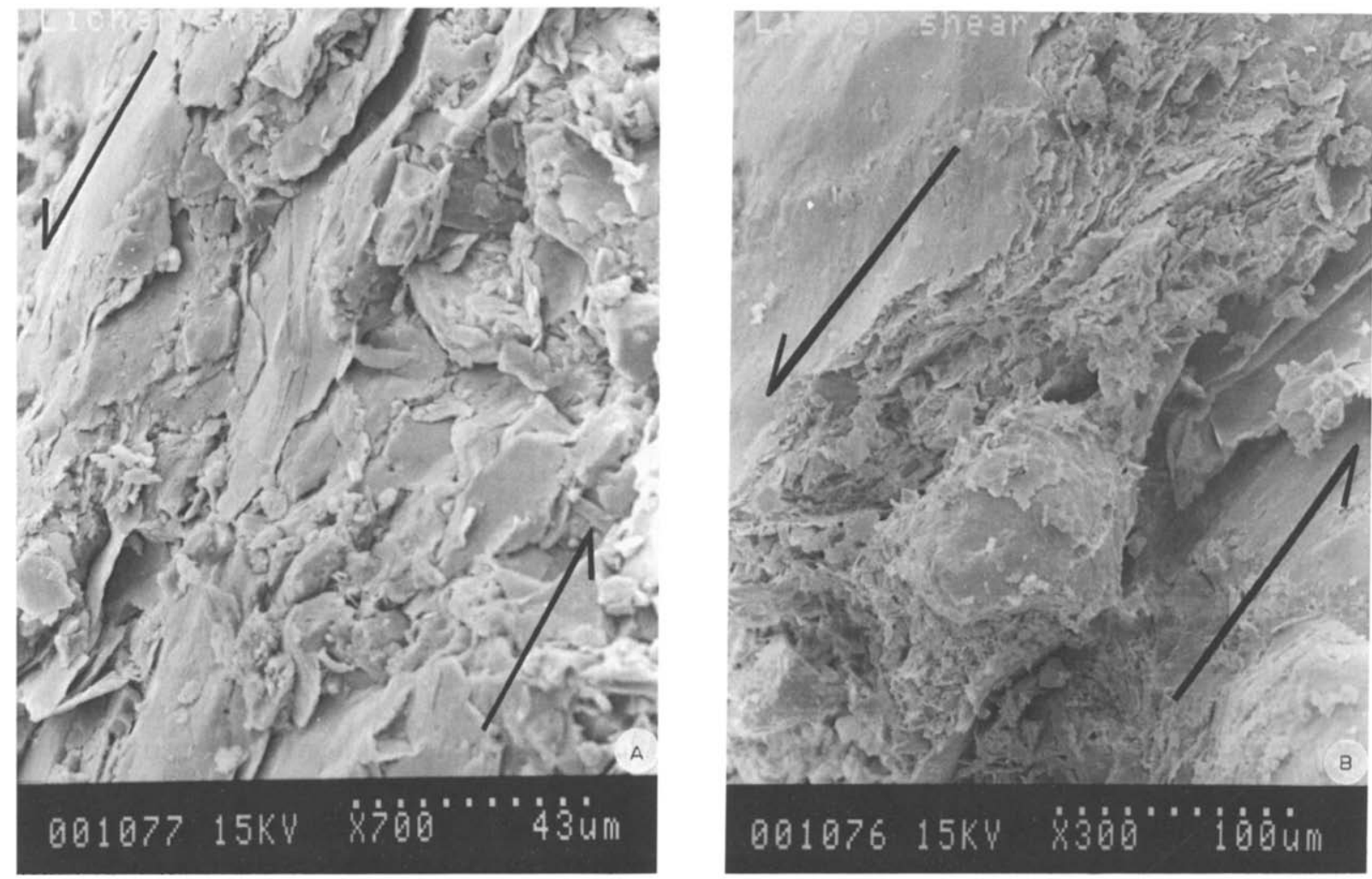

Fig. 11. Secondary electron photomicrographs of sheared silts and clays from within a shear zone in the Lichar Gah stream section.

$20^{\circ}$ to $30^{\circ}$ so that the orientation of the foliation of the gneiss within the landslide is steeper than on the Lichar Spur. At the toe of the slide a remnant of the Lichar thrust is present similarly rotated to a higher angle than on the spur. At the root of the slide a large depression filled with fallen blocks and screes is present typifing a rotated slide. Viewed from high up the Lichar Spur, many of the isolated blocks accurately relate to sheets of rock which have fallen from the spur, their lithologies matching up laterally. A large mound of till is also preserved on the slide.

\section{Ramghat Pul fault}

On the southern side of the Astor River near Ramghat Pul a large fault is exposed. The fault can be examined in a gulley; it has a thick (approximately $1.5 \mathrm{~m}$ ) clayey silt fault gouge (Fig. 13). Alignment of clay minerals within this gouge shows a downward sense of throw, downthrowing bouldery conglomerates with thin lenses of silts against high-grade Nanga Parbat gneiss. As a result of downfaulting, the sediments have become tilted to a steep angle (approx. 50-60 ${ }^{\circ}$ ) and a large block of gneiss has slid over the top of them, this is tilted at a similar angle. Overlaying these downfaulted sediments are two major diamicton units which probably have a debris-flow origin. Another major debris-flow diamicton uncomformably overlays these sediments and the fault does not penetrate it. This in turn is uncomformably overlain by fluvial sands and imbricated gravels. The sands are channelled by small channels $(<1$ $\mathrm{m}$ in depth) and they are infilled with pebbly sands. At some locations the sands are faulted by conjugate sets of normal faults with displacements in the order of several centimeters (Fig. 14) and kink bands are also recognised with an apparent stain hardening along their margins.

Whether this faulting relates to neotectonic deformation or dewatering of the sediment is difficult to resolve. However, this faulting is confined to this particular sediment and is clearly a func- 

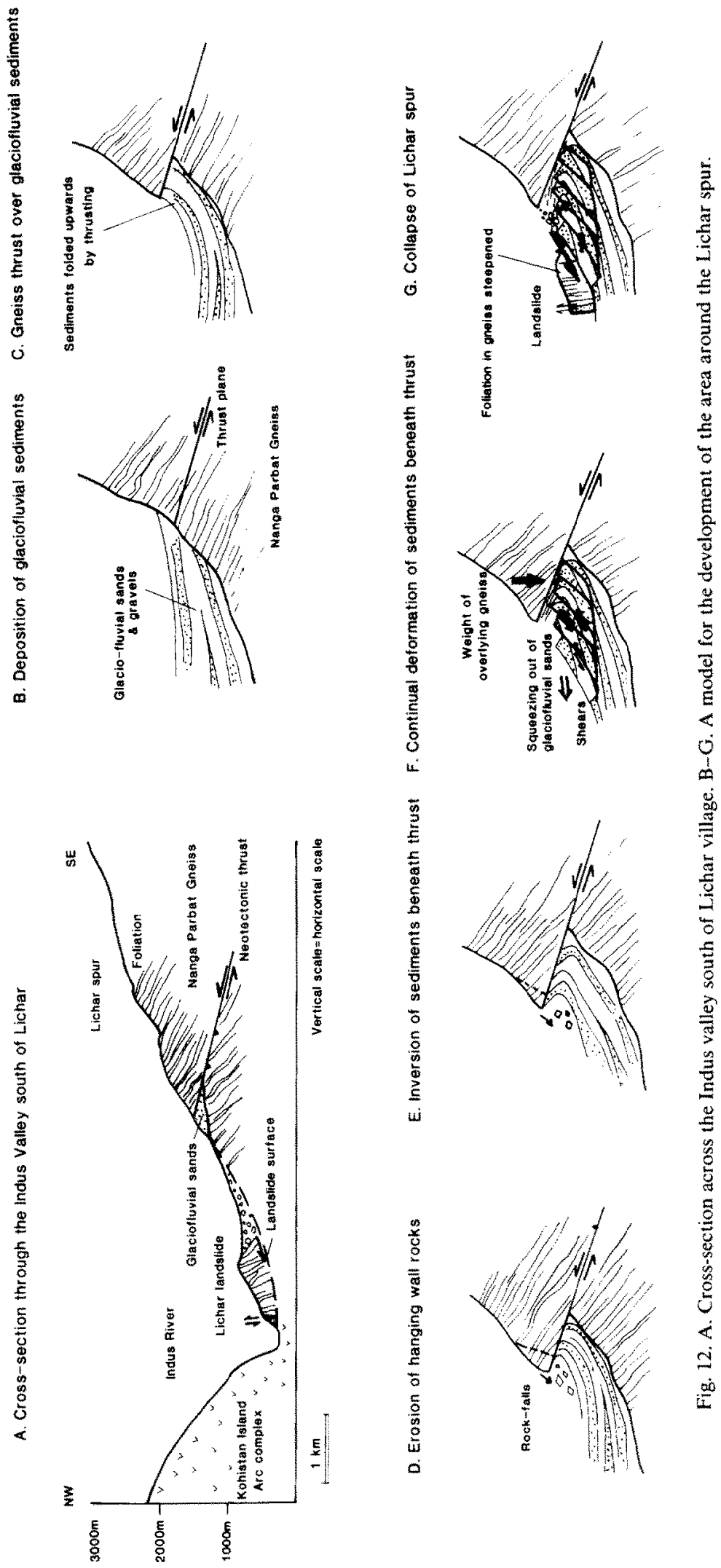


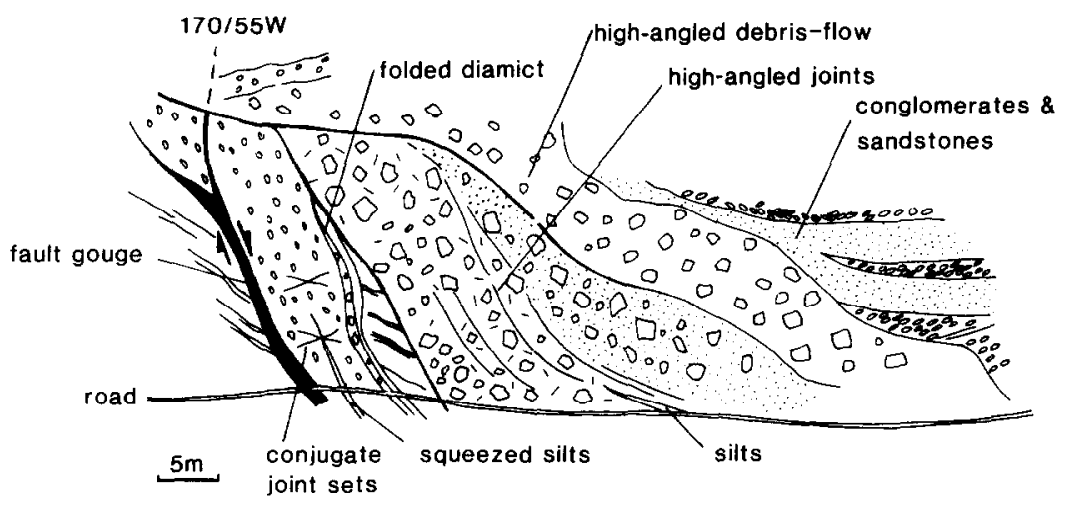

Fig. 13. Field sketch of the Ramghat Pul fault.

tion of the lithology, which either suggests that the sediment dewatered in a different way than the adjacent sediments or that its lithology was such that deformations of small magnitude could fault it whereas the coarser sediments would not deform. The silts within the diamicton units show no evidence of this faulting so the former conclusion is preferred.

\section{Lichar shear zone}

A cutting made by the Rakhiot-Astor road, 2 $\mathrm{km}$ to the north of Lichar, exposed sheared Nanga Parbat gneiss and sands (Figs. 3 and 15). The shears dip between $40^{\circ}$ and $80^{\circ} \mathrm{SW}$ and have an oblique upward or downward sense of movement. A dextral slip component has been recognised in microfabrics of the sheared sediments using the scanning electron microscope. The shears comprise an anastomosing system confined to a zone a few centimeters wide. Sheared thin pegmatites indicate displacements in the order of a few centimetres. The foliation within the gneiss is in the same orientation as the foliation in the Lichar spur indicating that there has been little rotation of the sheared blocks.

Incorporated within the foliated gneiss are pods and irregular shaped bodies of unlithified sands and gravels ranging from several centimetres to 5 $m$ in length. The contact between the sands and gneiss may be a shear or an irregular infilling between the walls of the fractured gneiss. The zones of sand are sub-parallel to the shears and may be partially bounded by them. However, some have no systematic relationship to the shearing and are oriented oblique to the shear orientation or may be faulted by the shears.

The sheared sand bodies have displacements in the order of centimetres. Locally the sands may be consolidated and a shear may fracture a large pebble or cobble within the sand. Other shears may not be as pervasive and either deflected around the pebble or become pinned when reaching the obstruction.

Pebble clusters are present within the sands, frequently parallel the shear orientation and indicate the same sense of shear movement. One sheet of sand has been folded and has a spaced axial planar cleavage. The contact above and below this sand sheet comprises an irregular nonstructural contact.

Some zones are complex having highly sheared admixtures of irregular blocks of garnet gneiss (differing from the surrounding foliated gneiss) and sand. Several shears have large displacements which juxtapose blocks of foliated gneiss and gneiss intruded by pegmatites. In the northwesternmost section faulting downthrows bedded sands against foliated gneiss with at least $5 \mathrm{~m}$ of downthrow. These sands are tilted at about $30^{\circ}$ towards the southeast and are gently folded with small fault-related joints. Other shear zones fault in blocks of gneiss which do not contain any sand pods. Thin lenses of silt line some of the major 

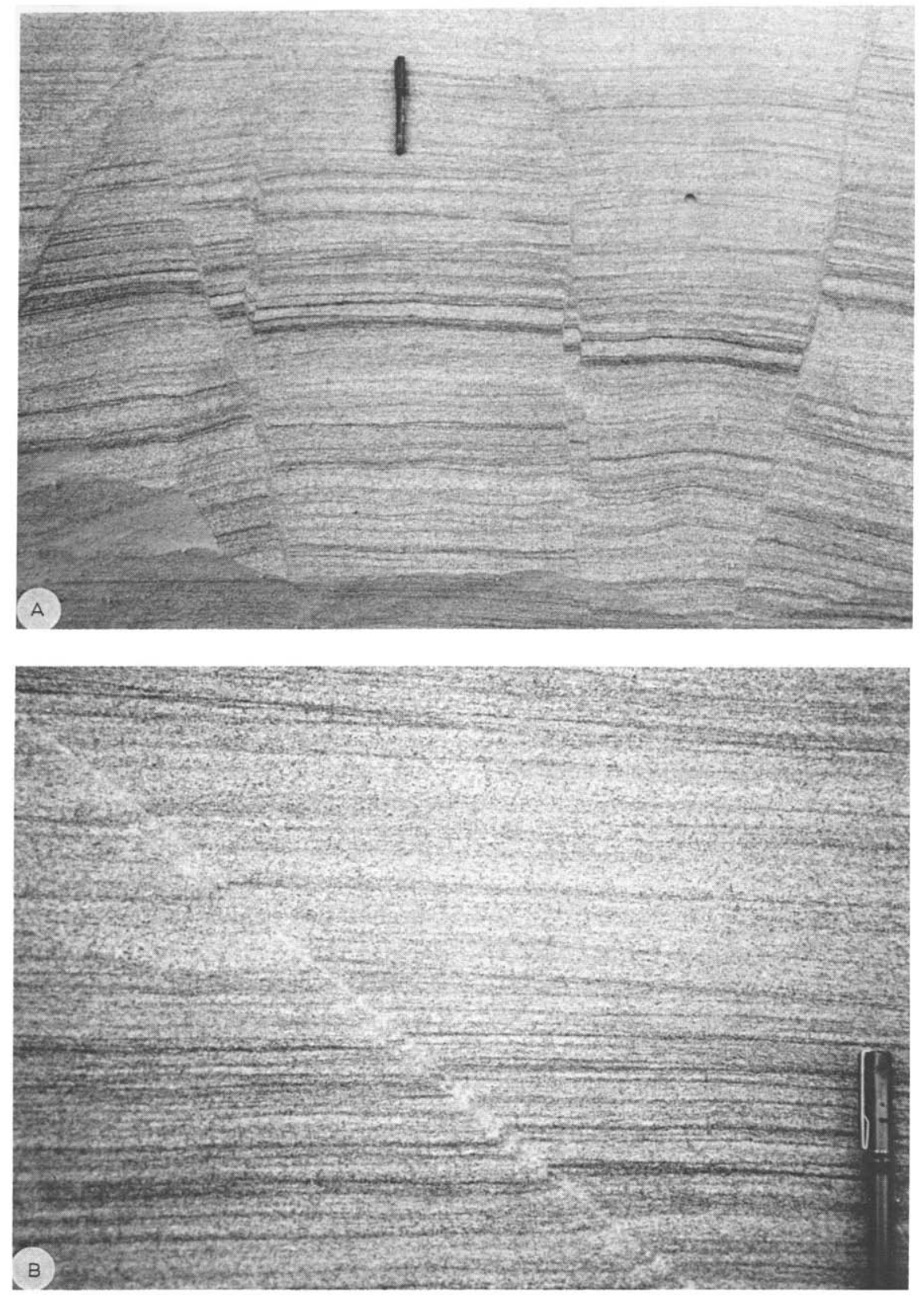

Fig. 14. Normal faults (A) and kink bands (B) in sands near the Ramghat Pul fault.

shears, but are usually only a few centimetres in length.

Several stages of development can be recognised in this shear zone (Fig. 16). Initially glaciofluvial sands were deposited over the Nanga Parbat gneiss (Fig. 16A). The gneiss was sheared by oblique strike-slip movement. Irregular undulating shear planes would have produced large zones of dilatancy which allowed loose sand to fall in from above (Fig. 16B, C). The sands were not strictly tectonically emplaced and the contact with the gneiss was an irregular infilling between the walls of the shear. Blocks of adjacent wall rock fell in and were incorporated into the sand producing a complex admixture. Movement of the sand within the infills, owing to continued movement due to 


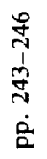
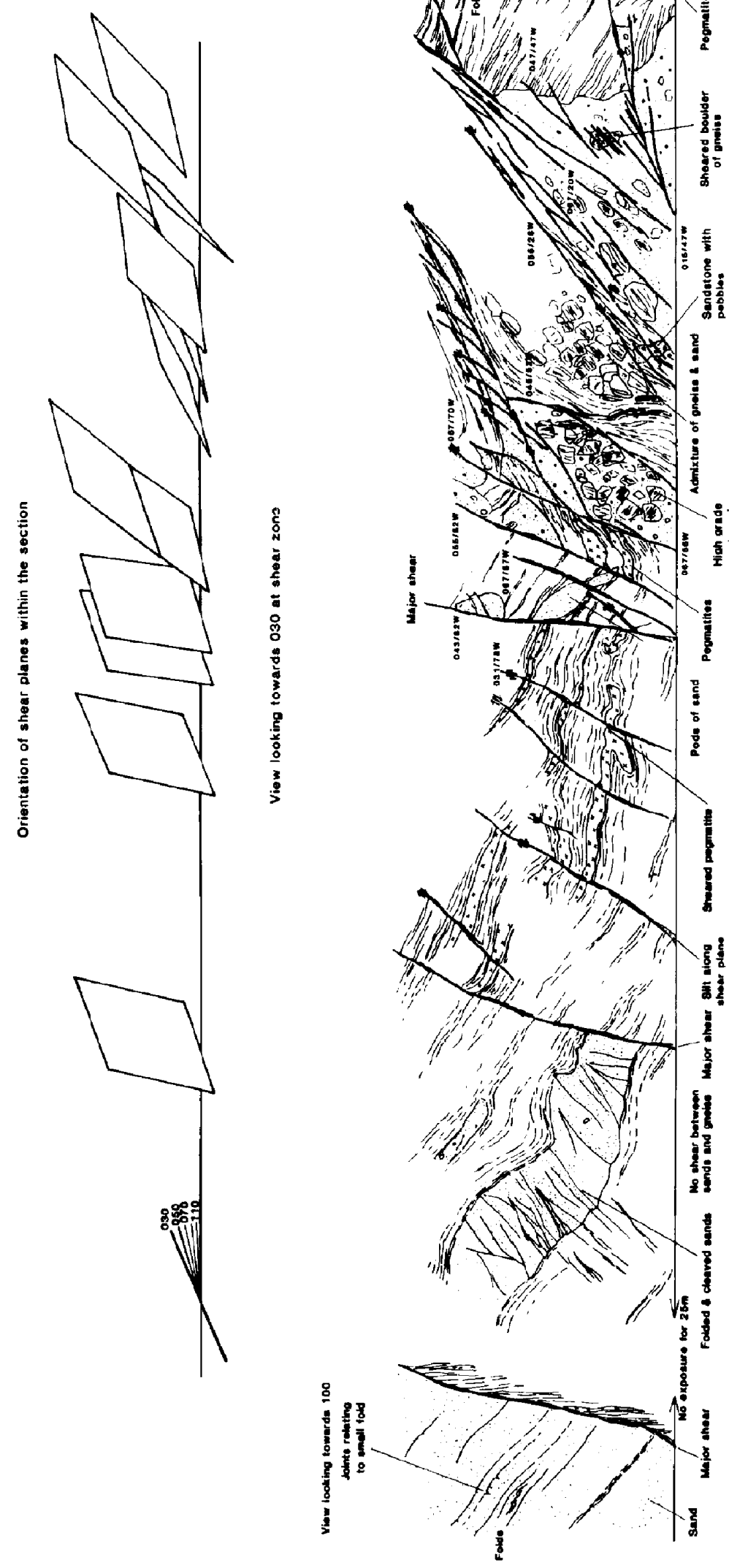
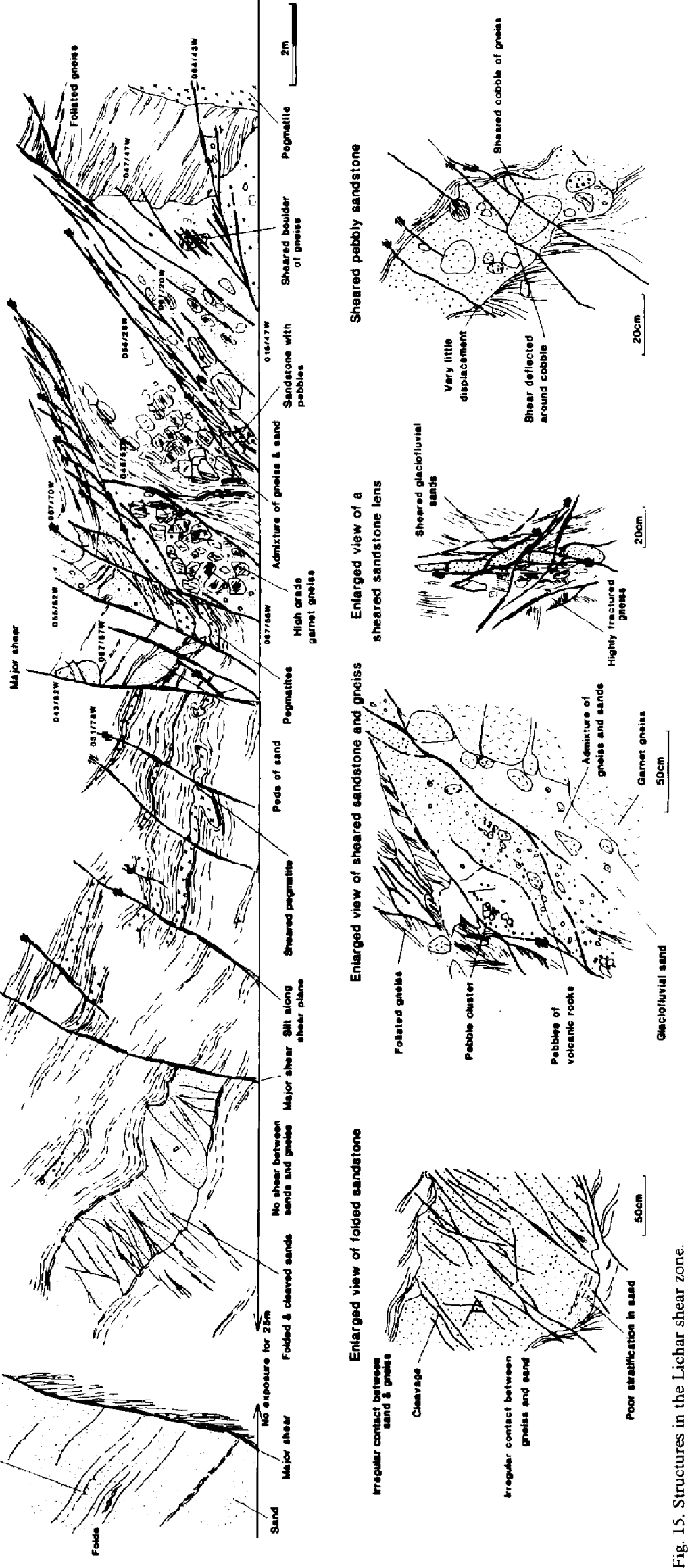

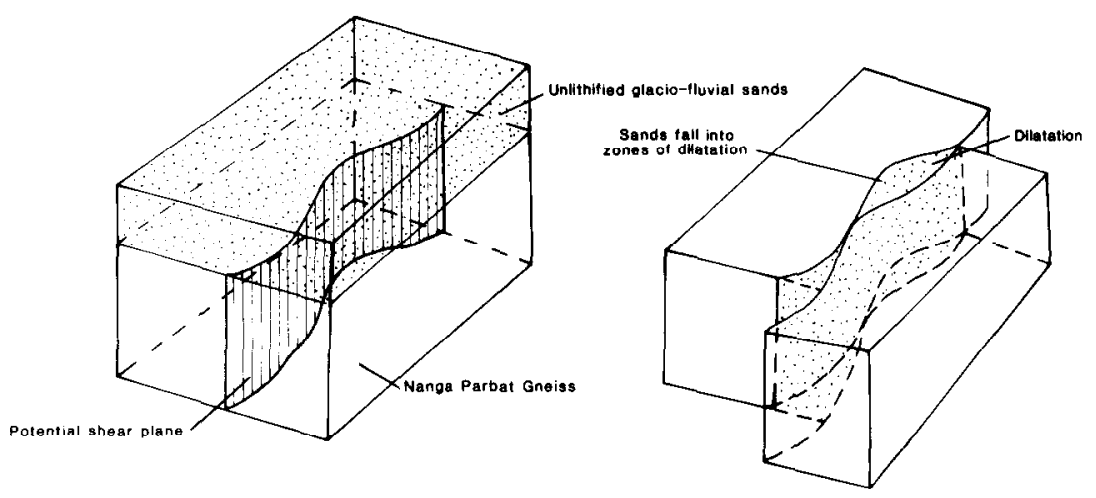

D. Potential sub-vertical shear plane

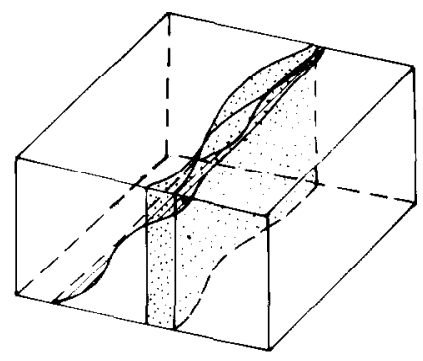

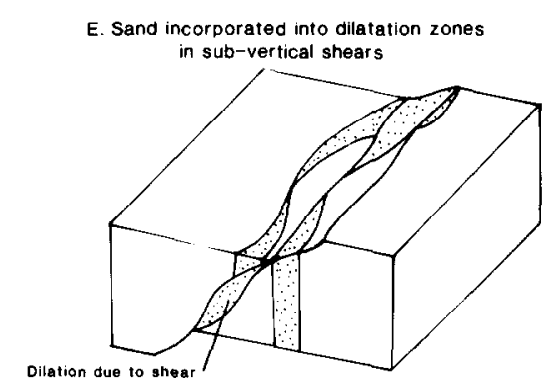

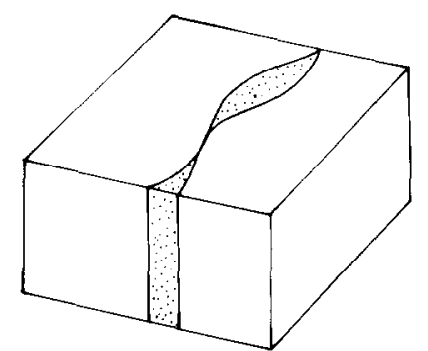

F. Continuing shearing of Nanga Parbat Gneiss and glaciofluvial sands

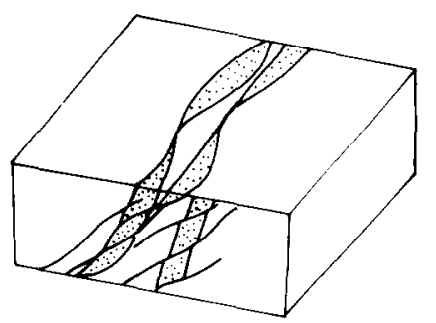

Fig. 16. A model for the development of the Lichar shear zone.

shearing, produced pebble clusters. Glacial ice may have been over the sands when the shear zone first started to move. This would help provide a confining pressure to aid the incorporation of sands into the zones of dilation. Later movement oblique to the early shear isolated infilling of sand producing pod shaped bodies of sand within the gneiss (Fig. 16D, E). Continued shearing would further deform the sand and gneiss often with just small displacements of a few centimetres (Fig. $16 \mathrm{~F}$ ). Larger shears are present but are less common.

This section was examined in October 1987 and January 1988. In October an impressive late shear penetrating a large cobble, but not displacing it, was examined (Fig. 17). In January the same cobble was examined again, however, it showed a clear sinestral displacement of $4 \mathrm{~cm}$ along a plane $35^{\circ} / 45^{\circ} \mathrm{W}$. Clearly this showed evidence of recent shearing along this zone between October, 1987 and January, 1988, indicating that the shear zone is still active.
A dextral oblique strike-slip component within the shear zones was determined by S.E.M. studies of the fine-grained material within the shears. This is consistent with a dextral shear sense within mylonites along the Rakhiot fault (Lawrence and Shroder, 1984). However, the shearing of the pebble described above during late 1987 shows sinistral movement which is not consistent with Lawrence and Shroder (1984) and does not help resolve the problem, suggesting that there is a combination of movement directions along this shear zone. These strike-slip movements may be a consequence of the culmination of thrusting around the Nanga Parbat syntaxis relating to its recent uplift.

\section{"Sandstone dykes"}

On the north side of the Indus valley $4 \mathrm{~km}$ east of Rakhiot Bridge a large exposure of amphibolite is present with till emplaced on its eastern end and 

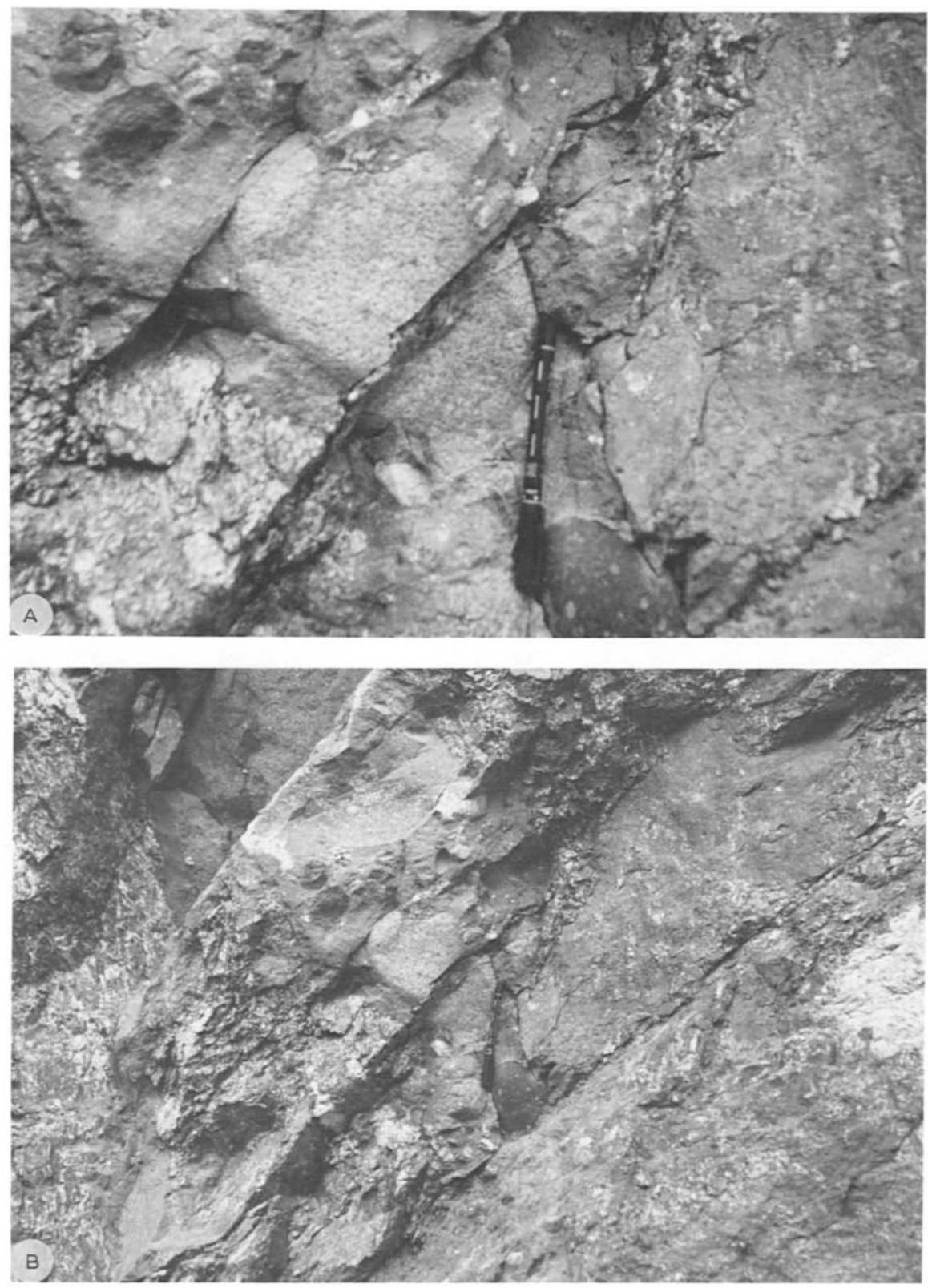

Fig. 17. A. Sheared pebble with no displacement along shear (October, 1987). B Sheared pebble with $4 \mathrm{~cm}$ of displacement (January, 1988).

overlain by well rounded pebbly conglomerates and lithic quartz wackes, forming what is essentially a "roche moutonnćc". Large dykes of sandstone are present within the amphibolite bedrock, which appear to fill major fissures (Figs. 18 and 19). Internally these dykes show a layering parallel to the walls with fine sands and silts along the margins grading into pebbly sands in the centre, occasionally large boulders are seen within some of the dykes. At one location the dyke is seen to be overlain by centimetres-thick, planar bedded coarse sandstones and well rounded pebbly sandstones which have sub-horizontal bedding. Similar dykes are seen east of Barchala Gah near the Karakoram Highway. Here they exhibit the same structure, but one particular dyke had rippled fine 

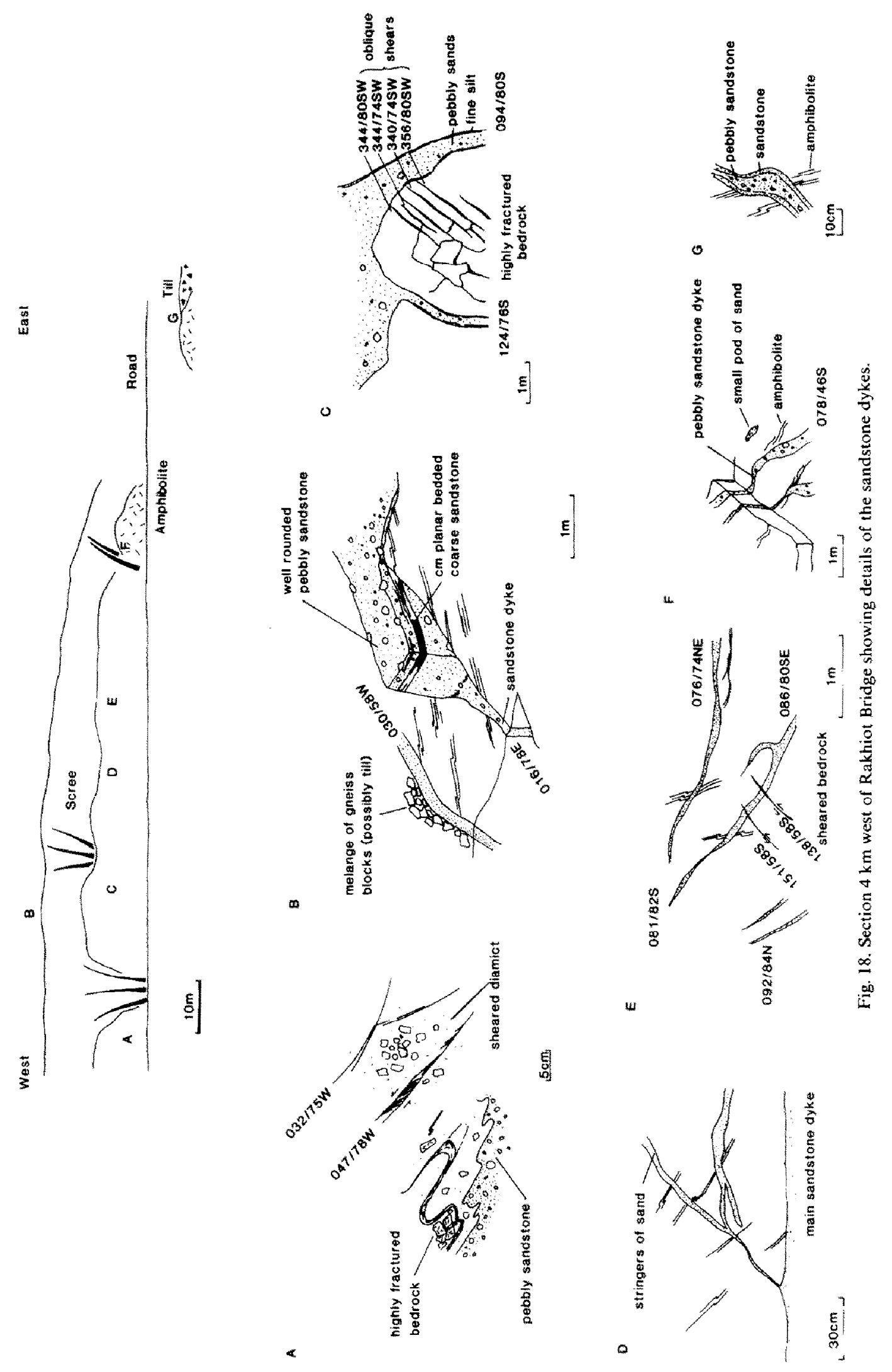


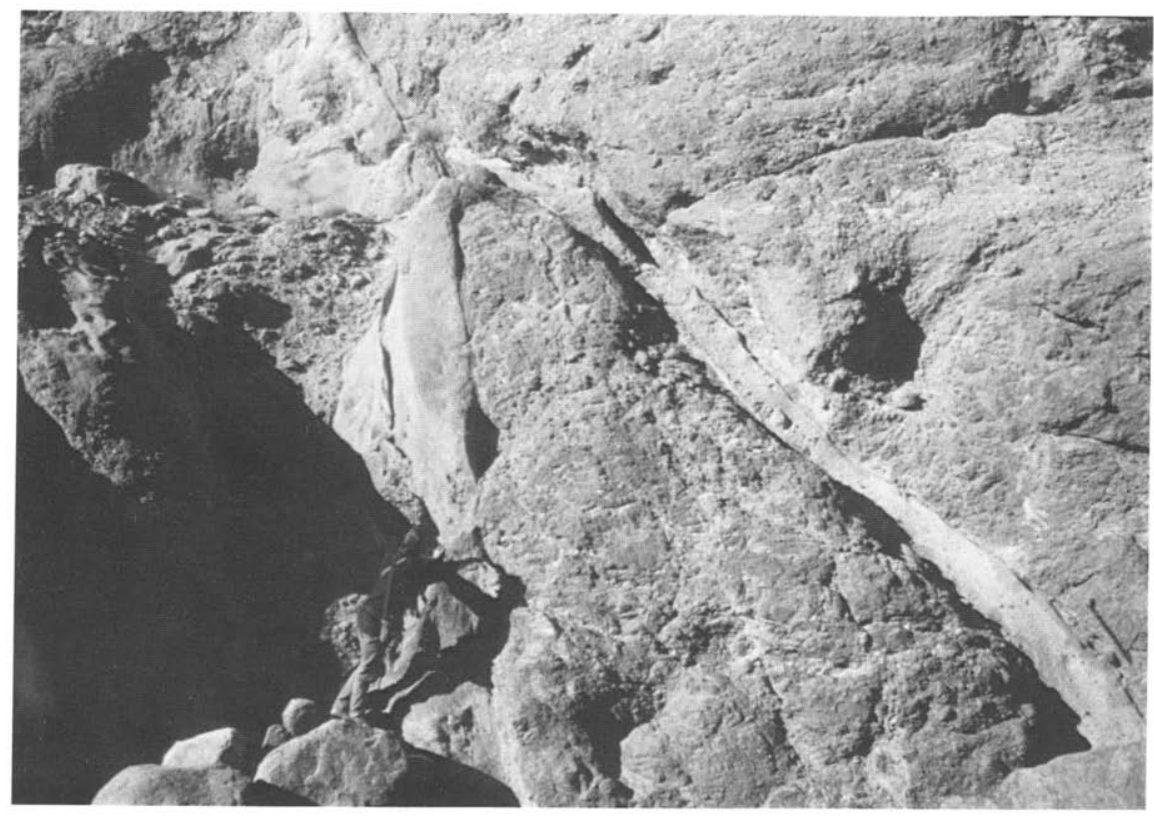

Fig. 19. Sandstone dykes near Rakhiot Bridge.

sands dipping at a high angle into one of the dykes. The stereonet in Fig. 20, shows the orientations of the dykes which are sub-vertical and vary in orientation from ENE to NE.

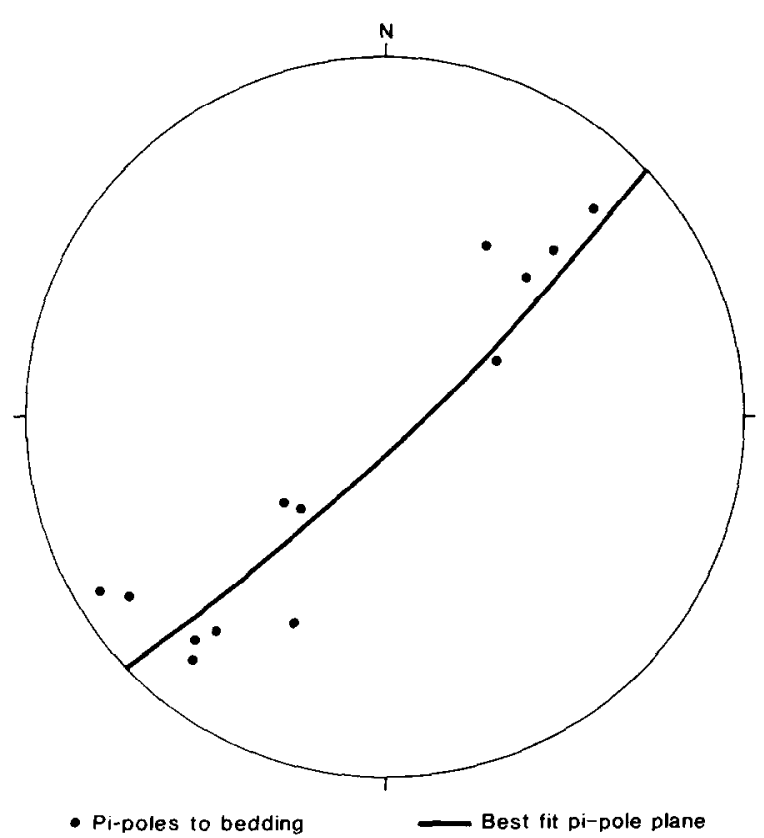

Fig. 20. Stcreonet for $\pi$-poles to the planes of the sandstone dykes.
A similar mechanism is proposed here for the formation of these "dykes" as was proposed for the formation of the sand bodies within the Lichar shear zone. That is, tectonic shearing created zones of dilatancy into which sand fell and was squeezed upon further shearing. The sands were effectively piped under pressure during shearing, causing the grain size differentiation parallel to the walls of the dyke. This resulted from an increased velocity gradient away from the walls of the dyke which causcd the fluid sand to flow slower due to friction and possible eddies caused by large protrudences. If valley ice was over the sands at the same time as deformation took place, this would have provided a confining pressure. The presence of rippled sandstones folded into the dykes and horizontal beds of sands overlaying the dykes suggests that deposition may be contemporaneous with deformation.

\section{Hot springs}

West of Rakhiot, near the village of Tattapani, a series of hot sulphurous springs are present (Fig. 3). These seep from silts and muds in terrace deposits, reaching temperatures in excess of $50^{\circ} \mathrm{C}$, 


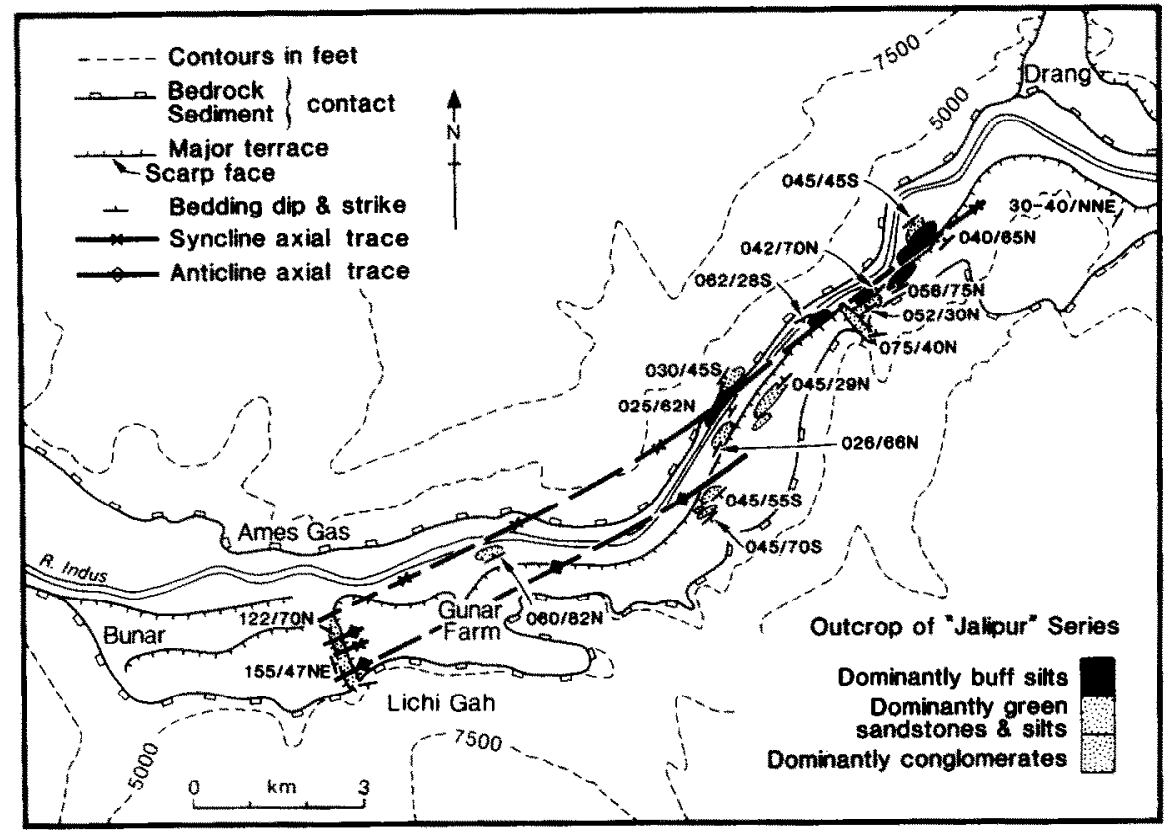

Fig. 21. Map showing the fold traces of the folded Jalipur sandstones.

calcareous and sulphurous deposits being precipitated. It is not possible to relate these springs clearly to a specific fault, but the valley bluffs to the south comprise Nanga Parbat gneiss and the rock immediately to the north in the Indus river bed comprises Kohistan volcanics. Accordingly, the MMT must be present along the zone near the springs and it is reasonable to relate the position of the springs to this fault zone.

\section{Folded "Jalipur sandstones"}

The Jalipur Group was first described by Misch (1935) as a series of well stratified grey micaceous sandstones and conglomerates, and indurated diamictons which Misch thought to be of Late Tertiary to early Pleistocene in age. These are deformed into a series of open folds with wavelengths in the order of hundreds of metres (Fig. 21) and are faulted in places. They are also complexly deformed at other locations but this can be attributed to glaciotectonic deformation and will be discussed later. Olson (1982) also described some of the sections and mapped their outcrop but did not produce a structural map. Olson (1982) assigned a younger age to these deposits than Misch (1935) on the basis that they contain pebbles from the Nanga Parbat massif which must be

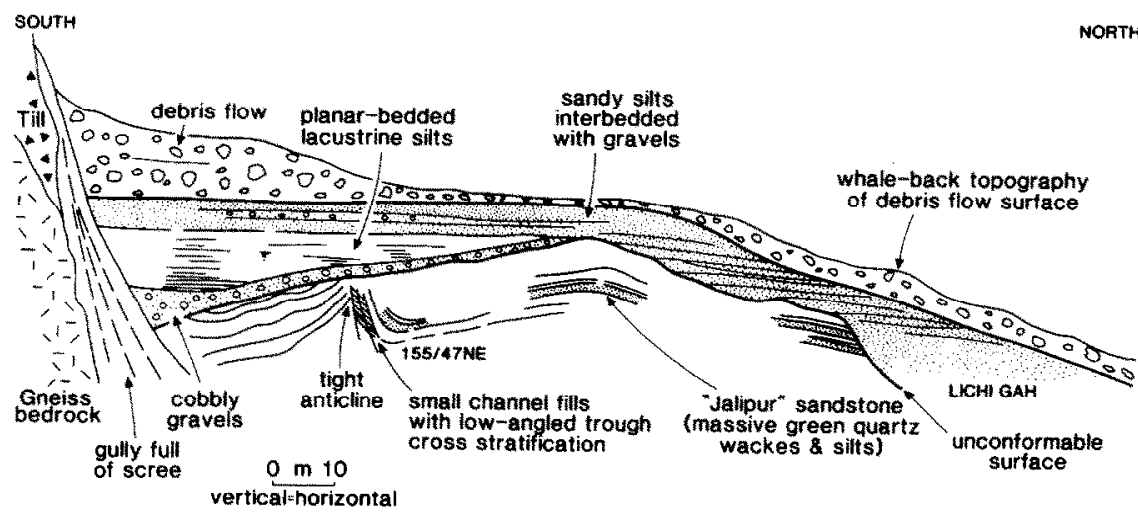

Fig. 22. Section through one of the folds which deform the Jalipur sandstones, Lichi Gah. 
younger than 2 Ma years based on work of Zeitler et al. (1985). Owen (1988b), from field mapping and correlation with dated deposits in the Hunza valley, showed that these were much younger and probably relate to Derbyshire's et al. (1984) Yunz Glaciation (c. 65,000 yrs B.P.). Also the Jalipur sandstones outcrop below 100 to $200 \mathrm{~m}$ above the present level of the Indus River. In view of their position with respect to river level they could not have been uplifted far and are clearly not related to old high glacial surfaces. They are therefore considered to be equivalents to the Yunz glacial sediments in Hunza valley $(139,000 \pm 12,500$ yrs B.P.). There is no evidence that these deposits have been downfaulted.

The Jalipur Group can be divided into four formations, a basal well indurated diamicton, polymictic conglomerates with green quartzwackes, green quartz-wackes and lithic quartzwackes, and planar bedded buff-coloured silts and quartz-wackes. Two major open folds with wavelengths in the order of hundreds of metres can be traced south of Drang for about $15 \mathrm{~km}$ (Fig. 21). At some locations the sandstones are faulted by thin sub-vertical centimetre-wide zones of anastomosing shears. Figure 22 shows a section through a major anticline in the Jalipur Group along Lichi Gah. Soon after folding of the sandstones they were eroded, but the anticline produced a sufficient high for water coming out of the Lichi Gah to be trapped and to form a small lake. Cobbly conglomerates and planar-bedded slits were deposited within this lake and upon filling the depression sandy silts interbedded with gravels were disconformably deposited on top. These are overlain by a bouldery diamicton which has a whaleback surface. These are probably debris flow sediments deposited by the resedimentation of till from the valley sides. Remnants of this till can still be seen high up the adjacent valley sides.

Steep $\left(30-45^{\circ}\right)$ NNW-dipping well consolidated conglomerates and sandstones are exposed along Barchala Gah, $8 \mathrm{~km}$ west of Rakhiot Bridge. Southward up the valley the upper conglomerates onlap an irregular erosional surface of Nanga Parbat gneiss. Lower down the sequence the relationship between the conglomerates and gneiss is less well defined. Locally gneiss overlays con-

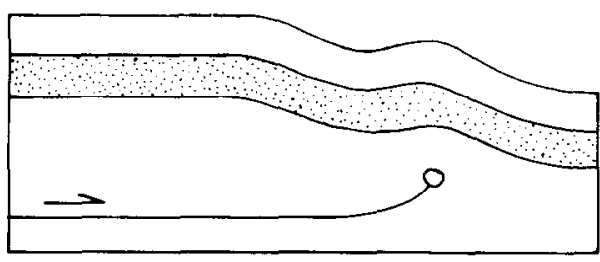

Fig. 23. Anticline syncline fold pair which can be produced above a ramping thrust (after Morley, 1985).

glomerates and may represent a small palaeo-overhang, a large rock slide or more likely a small thrust.

There are two main ways these folds may have developed:

(a) Simple folding of the superficial sediments due to the compression of the collision between the rocks of the Indian plate (Nanga Parbat gneiss) and those of the Kohistan island arc sequence.

(b) Anticline-syncline fold pair produced above a ramping thrust (Morley, 1986), (Fig. 23).

The latter of the two mechanisms seems the most plausible. It is difficult to produce such systematic folding, if the collision was the result of northward movement of the valley sides on the southern side of the Indus River with respect to the northern side. As seen elsewhere along the valley, deformation takes place along discrete zones. It is more reasonable to suggest that this would be the case in this area with a ramping thrust producing an anticline-syncline fold pair. This may also explain the apparent small thrust in Barchala Gah.

\section{Structural analysis of the Rakhiot area}

Figure 24 shows the orientation of the main structures in the Rakhiot area and the theoretical maximum principal stress direction for each of them. There is a systematic rotation of the maximum principal stress direction across the region which is normal to the trace of the MMT. It therefore is reasonable to suggest that these neotectonic structures relate to the MMT and are a result of the space problem induced by the divergent thrusting around the Nanga Parbat syntaxis. Alternatively it may be argued that this apparent rotation of the stress field is a function 


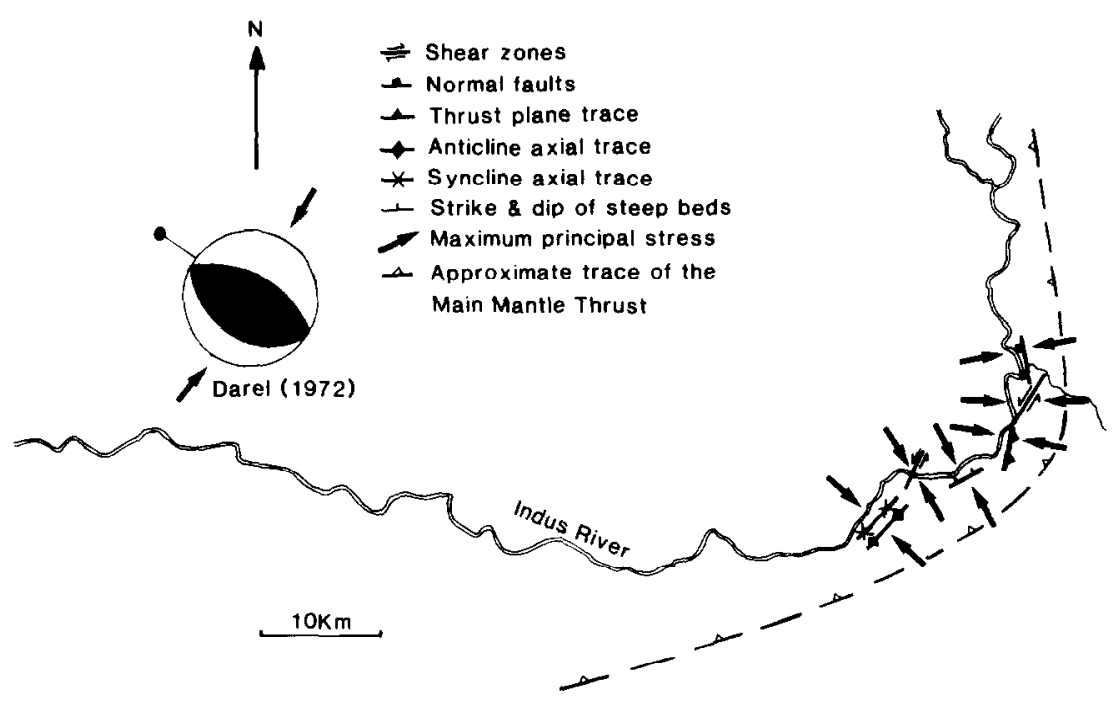

Fig. 24. Map of the middle Indus area showing the maximum principal stress directions for the neotectonic structures in this area.

of time, i.e. the maximum principal stress direction changed with time. Or it may be suggested that these structures have been folded by NE-SW compression late in this history and that the original maximum principal stress direction was in the same orientation for all the structures. The latter seems highly unlikely and is not supported by the structural analysis of the bedrock geology (Butler and Prior, 1988). Fault-plane solutions of recent earthquakes in Kohistan do indicate NE-SW compression, so the idea of later folding of these structures can not be totally ruled out.

\section{Debris-slide deposits}

Five kilometres east of Rakhiot Bridge on the south side of the Indus valley sheared conglomerates are present. No original bedding can be recognised within the conglomerates, but the clasts are well rounded and polymictic typifying a

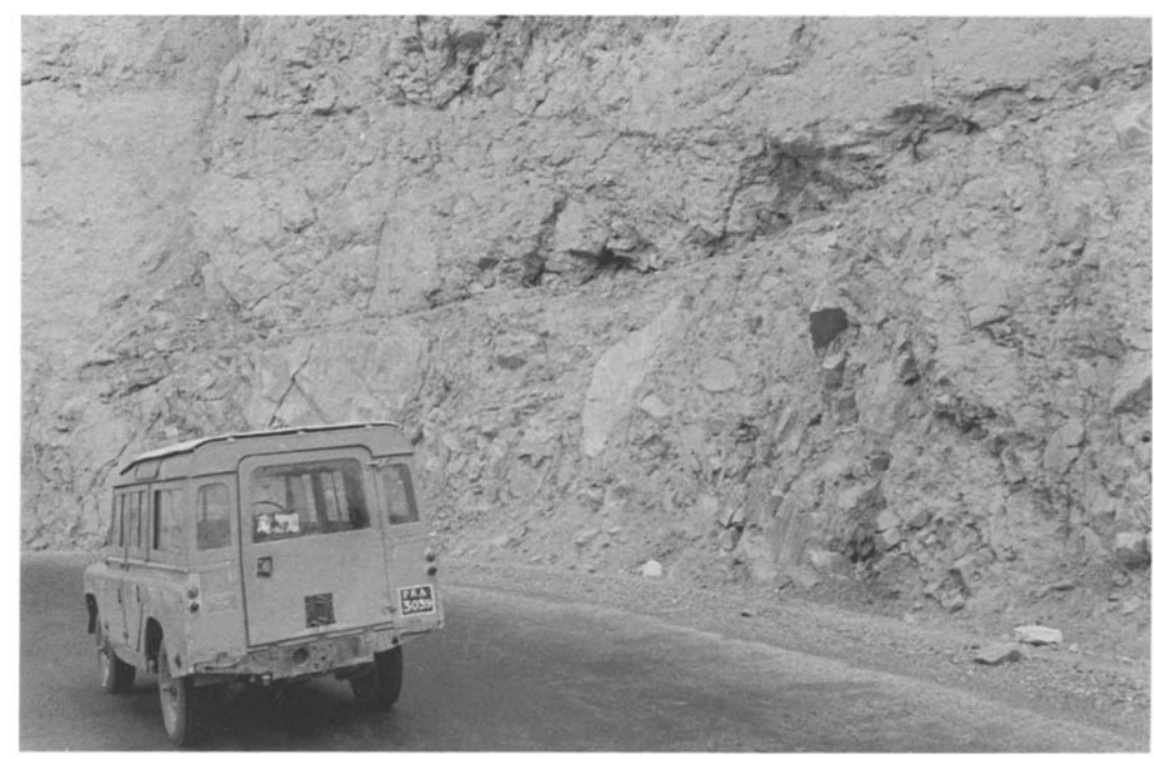

Fig. 25. A low-angled debris-flow showing a desiccation surface between two flows, in the lower Gilgit valley. 


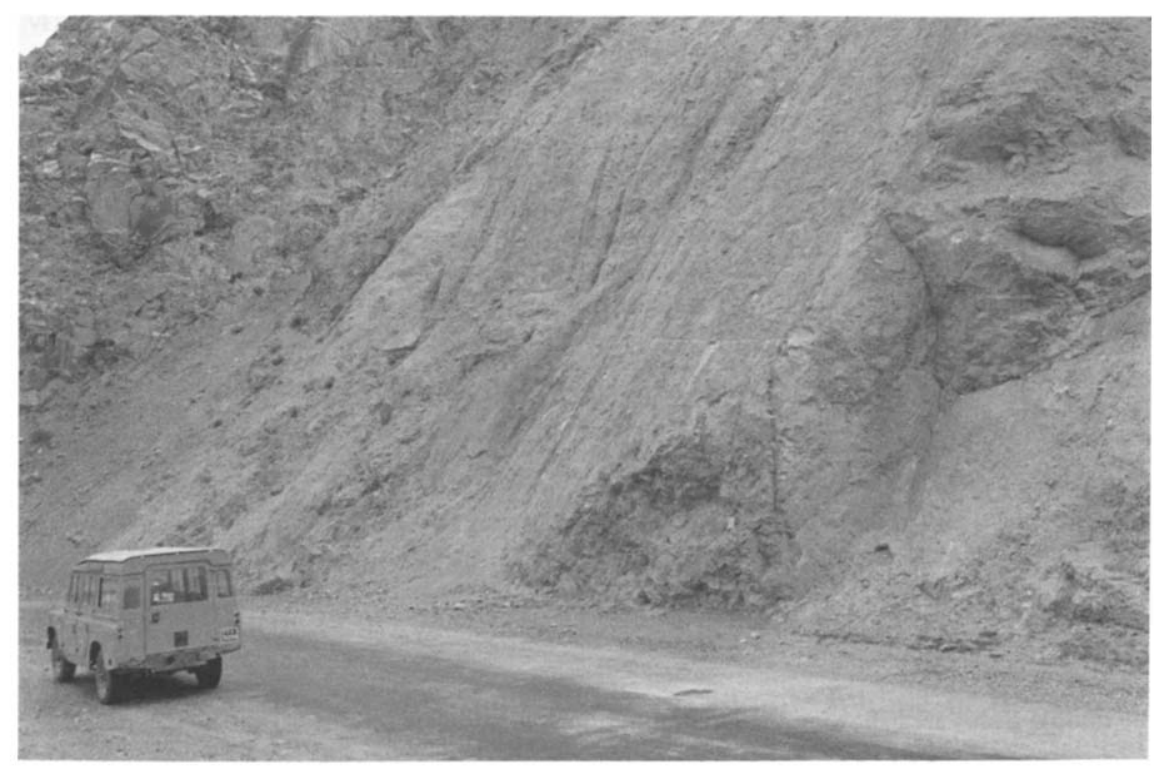

Fig. 26. A high-angled debris-slide with lateral and basal shear surfaces, lower Gilgit valley.

well worked fluvial sediment. The conglomerates are well consolidated and some have a weak carbonate cement. Two sets of shears are present, a subvertical northerly-striking set and a set dipping $30-50^{\circ}$ towards the north. The easterly striking set may be spaced at intervals of the order of 1-2 $\mathrm{m}$ and may shear through pebbles and frequently have slickensides. At some horizons a distinct discontinuity is present paralleling the low-angled easterly striking shears. These are lined with silts and sands and have poorly developed desiccation shrinkage cracks. The northerly dipping set may similarly shear through clasts but a few distinct sedimentological discontinuities are present which may be closely spaced.

At other locations in the lower Gilgit Valley similar structures are seen in diamictons (Figs. 25 and 26). Two sets of shears are also recognised. One set is gently inclined at $30-40^{\circ}$ striking parallel to the valley side and a second set is sub-vertical and normal to the valley side. The deposits also show desiccation surfaces sub-parallel to the low-angled shears. Their morphology clearly relates to the valley slope and they can be easily identified as debris-slide deposits. The morphology of the deposits east of Rakhiot is more difficult to observe but, seen from oblique aerial photographs, they clearly relate to debris-slides that have slid northward down the valley bluff between Rakhiot Gah and Barchala Gah.

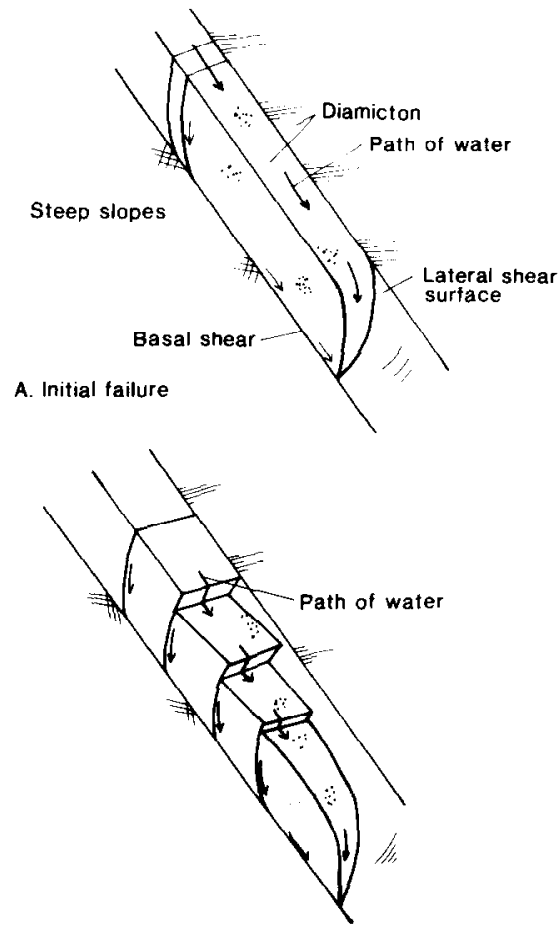

B. Debris becomes overconsolidated

Fig. 27. Diagrams showing the formation of debris-slide structures. 
Two phases of development can be recognised (Fig. 27). An initial failure which produced a major slide of debris bound by basal and lateral slide surfaces. The second phase produced a more closely spaced brittle failure due to an increase in strength of the material during dewatering or weak cementation.

After sliding ceased, a thin veneer of sand and silt partially deposited by bleeding of water from the slide or by an aeolian input was deposited on top. This surface was then desiccated before the next slide. The debris-slides in the lower Indus valley show all graduations between low-angledpoorly sheared slides to steep-angled slides, and they form a common component of the valley fills (Figs. 25 and 26). These structures may be easily mistaken for structures produced by neotectonic faulting.

\section{Glacially deformed sediments in the Rakhiot area}

The Indus valley and its tributaries in the Rakhiot area have been glaciated and glacial sediments have been deposited along them. Many of these have been deformed by glacial as well as neotectonic processes. Eight glacial stages have been identified in the Karakoram Mountains (De- rbyshire et al., 1984). Three main Pleistocene glaciations produced extensive ice cover:

(3) Borit Jheel-65,000 $\pm 3,300$ to $50,000 \pm$ 2,500 yrs B.P.,

(2) Yunz-139,000 $\pm 12,500$ yrs B.P.,

(1) Shanoz-age unknown.

Five less extensive Holocene glaciations are also recognised but are of little importance in this study. Only isolated erratics remain from the Shanoz glaciation. The Yunz and Borit Jheel glaciations were phases of extreme trunk valley glaciations in the Hunza valley and produced major valley glaciers that extended down the middle Indus valley depositing till-sand associated sediments. In the Rakhiot area evidence for the Borit Jheel and Yunz glaciations is easily recognised. Isolated exposures of Jalipur tillite are presently exposed in the river terraces along the Indus (Fig. 3). Glacially induced thrust structures and folds in the tills, and associated glaciofluvial sediments indicate ice movement directed down valley. The northernmost exposure of Jalipur tillite is present $7 \mathrm{~km}$ north of the Astor-Indus confluence, indicating that ice moved southwards down the Indus as far as Buldar Gah.

There is no evidence that Nanga Parbat ice extended further northwest than Tato and Muthaf

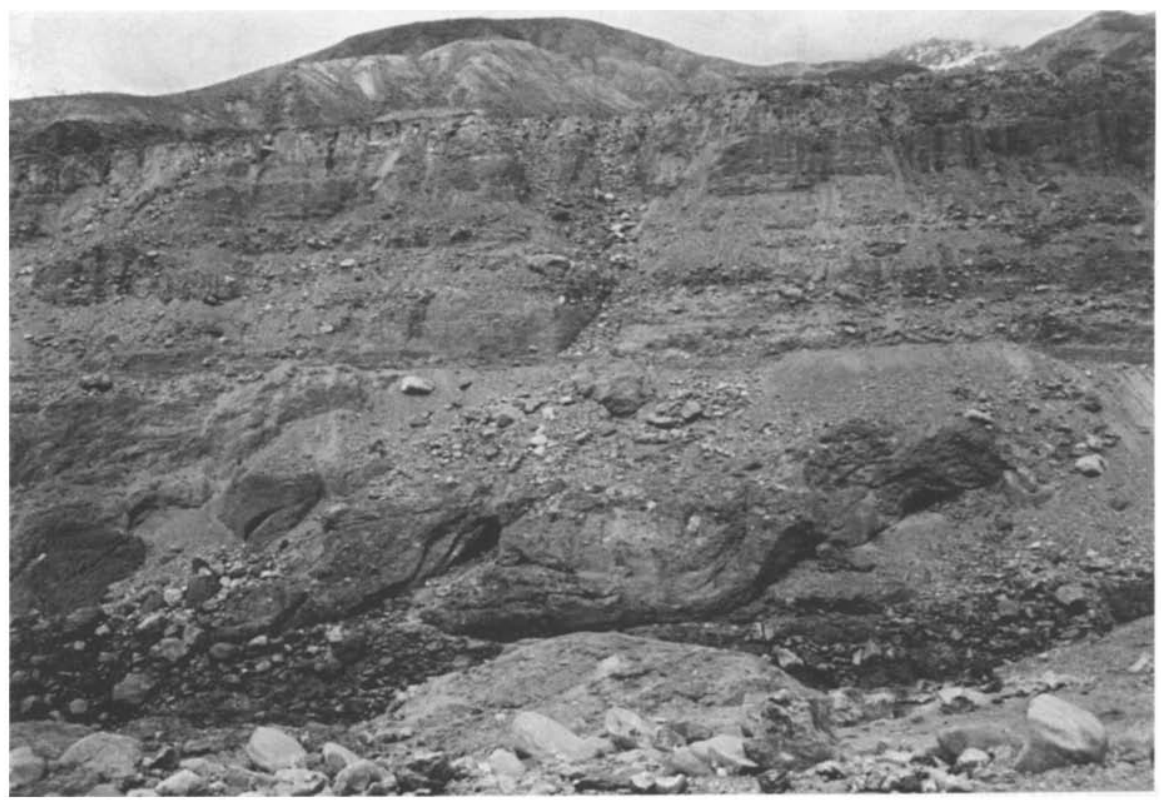

Fig. 28. Jalipur tillites thrusted over glaciofluvial sands near Tattapani. Note the Karakoram Highway for scale. 

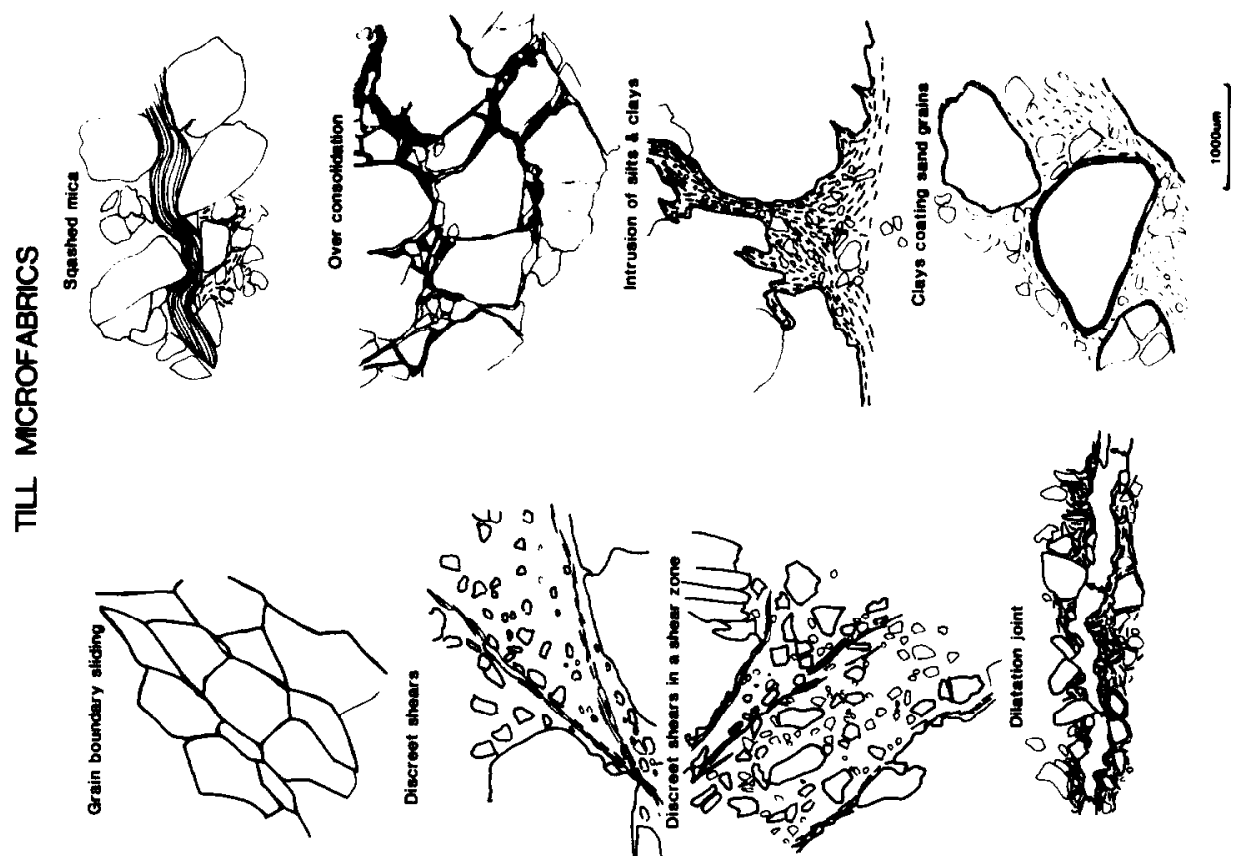

$10 \%$ oñ:
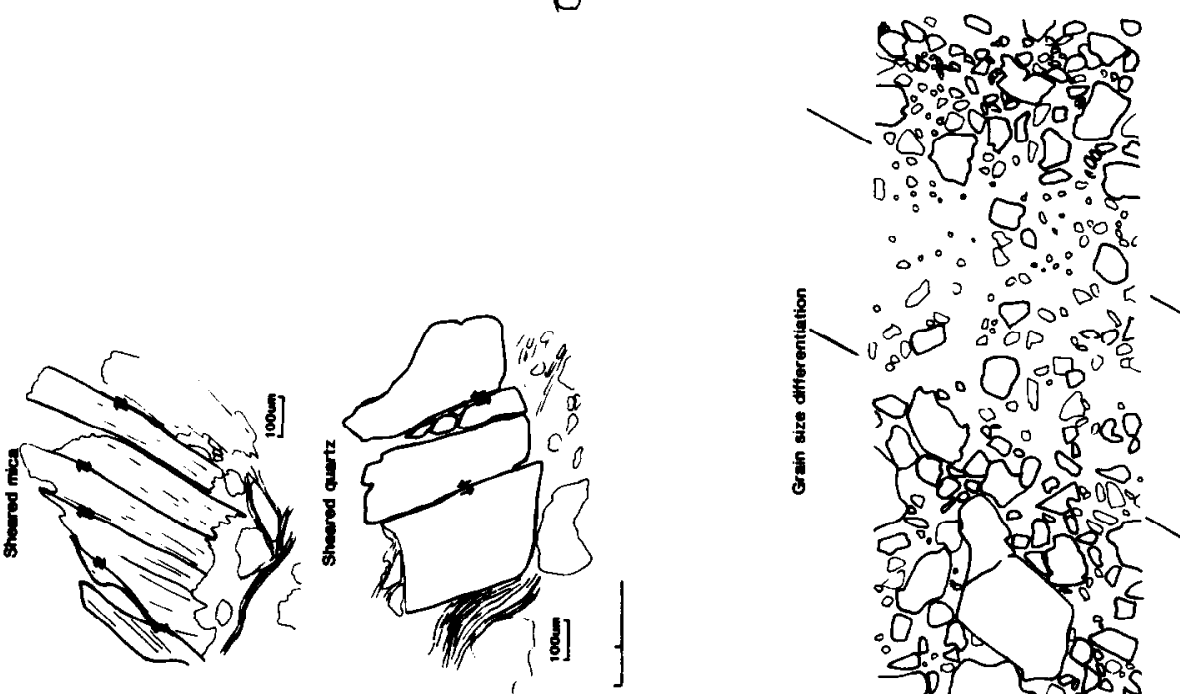

$0 .: 20$ है

$\therefore 00000$
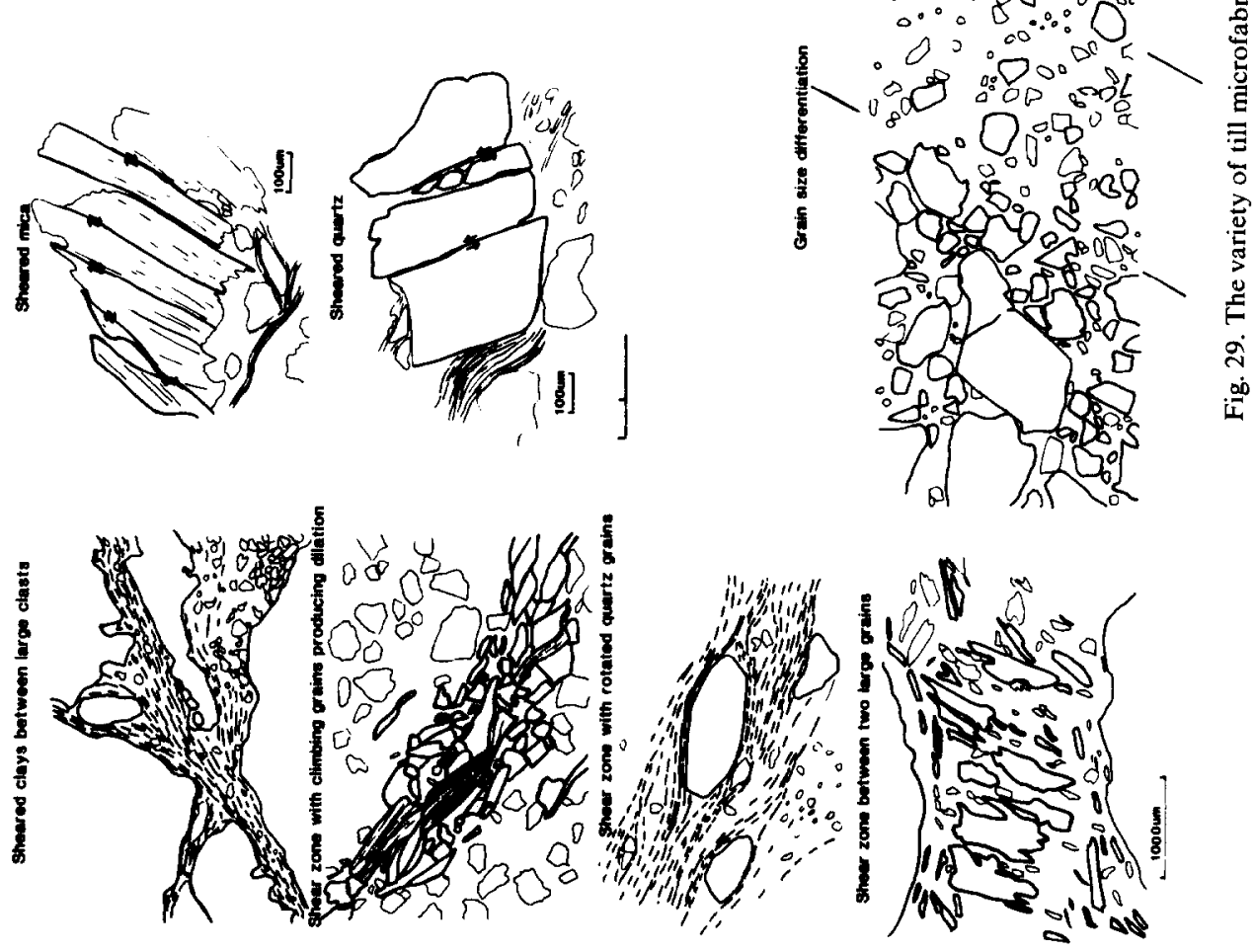


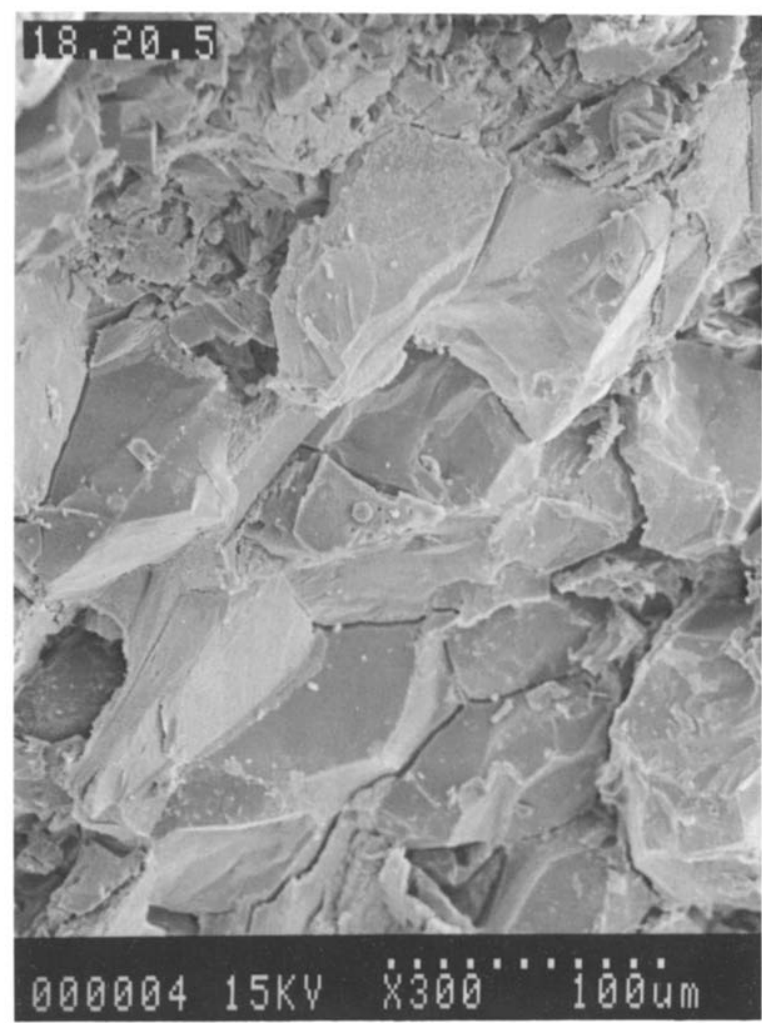

Fig. 30. Secondary electron photomicrograph showing grainboundary sliding within the Jalipur tillite. and the tills at these locations are younger than the Borit Jheel glaciation (Owen, 1988b). Therefore tills in the Indus valley relate to major trunk valley glaciers.

The majority of the Jalipur tillite is of lodgement origin, which involves the deposition of till under the sole of the glacier by a process of shear, compaction and flow. This produces a whole range of structures which without due care may be misinterpreted as neotectonic.

Glacial and non-glacial sediments that have been overridden by glacial ice may deform due to the ice overburden, or push by the ice movement and shearing. Adhesion of wet sediment to the base of a glacier may produce thrusting and folding of sediment. The structures produced are as follows:

\section{(1) Thrusts and shears}

Thrusting and shearing are present in most sections: typically, till is thrust over glaciofluvial sediments. The thrust planes are usually very discrete with little deformation outside the thrust zone (Fig. 28). The thrust movement may be several centimetres to tens of metres. When thrusts

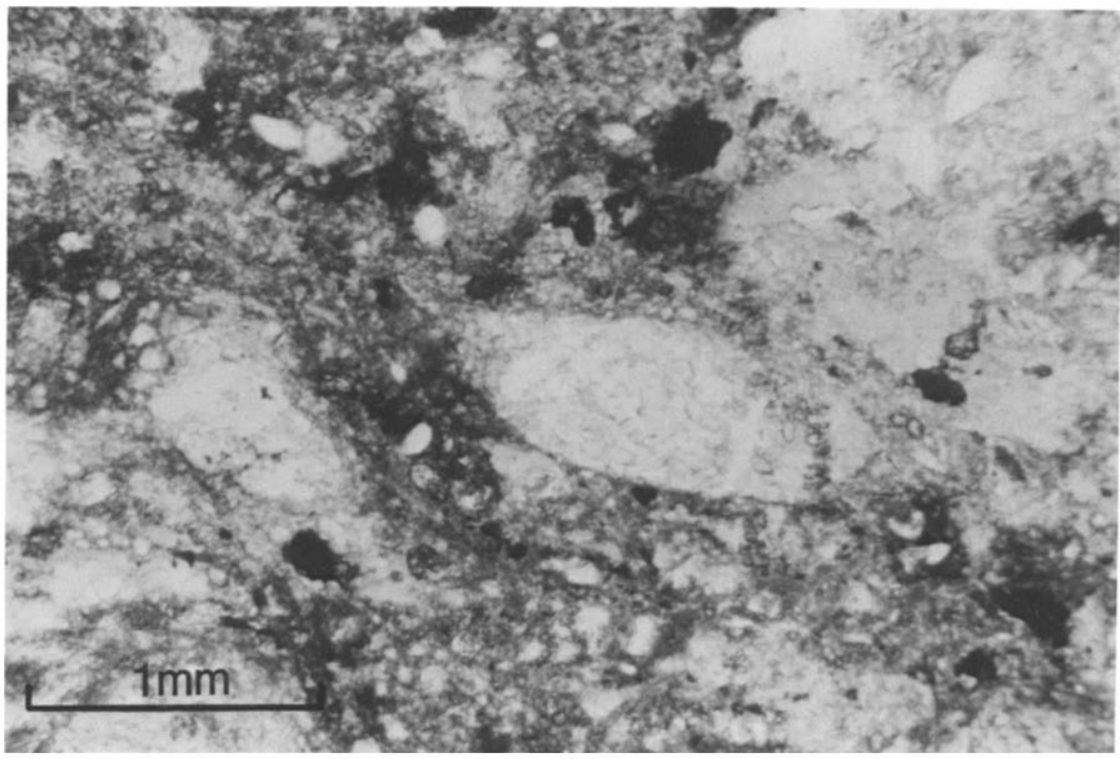

Fig. 31. Photomicrograph of a thin section of shear Jalipur till showing a rotated quartz grain in a shear clay matrix. The field of view is $\mathbf{4} \mathbf{~ m m}$ in cross-polarised light. 

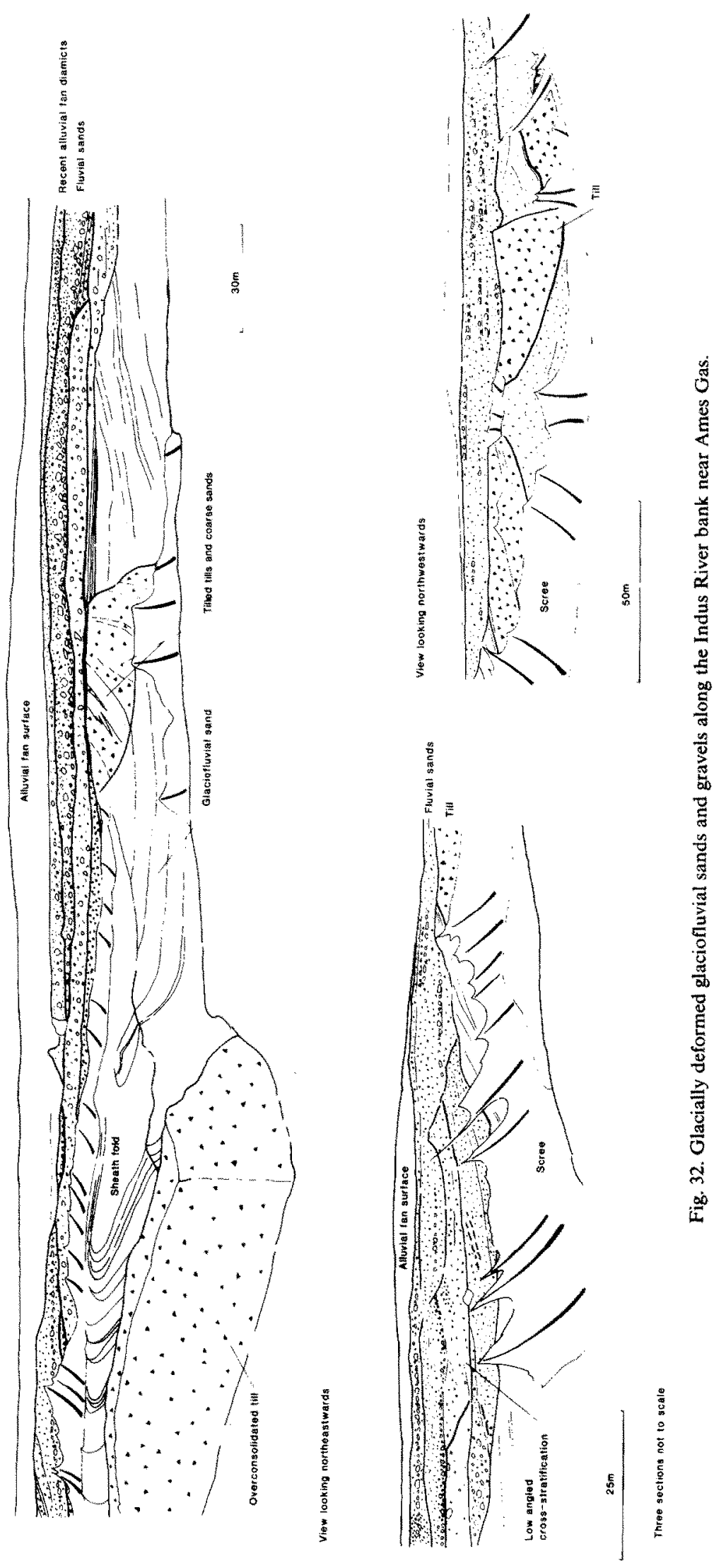


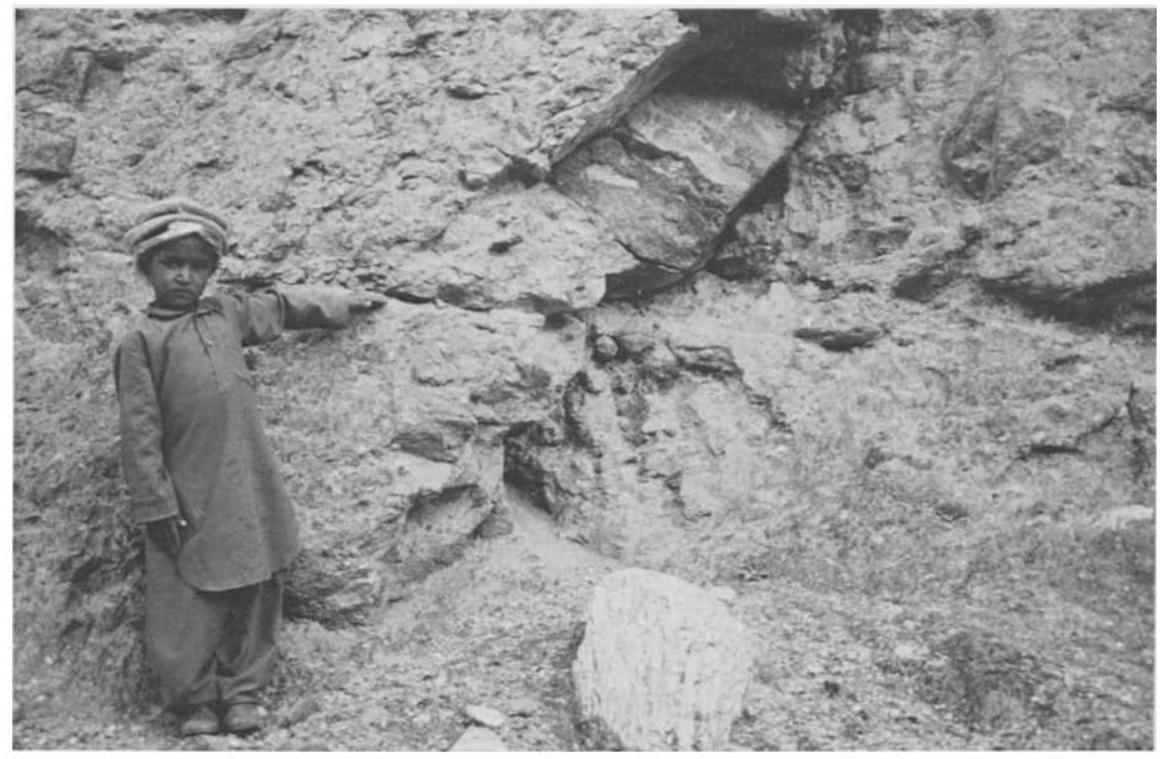

Fig. 33. Overconsolidated Jalipur tillite with a dilatancy joint below the boy's hand and a shear zone at the top of the photograph

are present within bedded sediments, thrusting exploits bedding planes until it climbs into higher beds. Shearing is usually on a smaller scale and is most common within the tills themselves. The styles of shear may be of several types (Fig. 29): (a) Grain-boundary sliding where sand and silt grains in tightly a compacted zone slide over one another (Fig. 30). This may also produce zones of dilation within the till sediment.

(b) Discrete shear zones where sub-parallel to

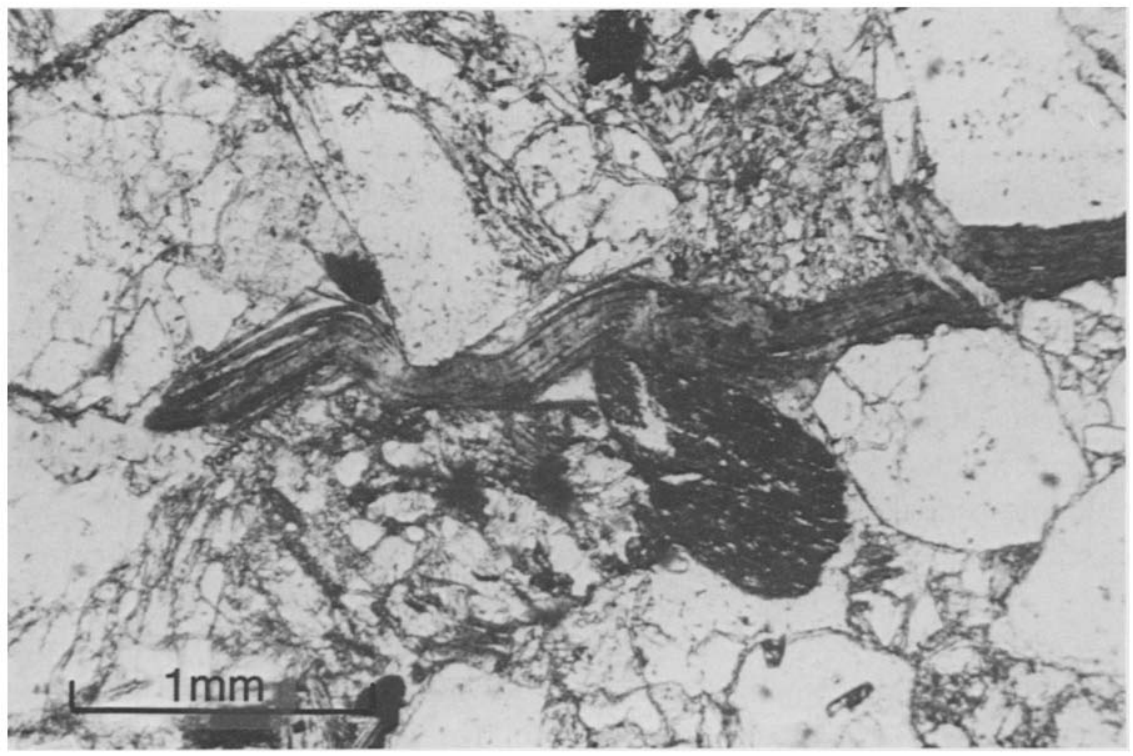

Fig. 34. A photomicrograph of a squeezed mica within overconsolidated Jalipur tillite. The field of view is 4 mm, in plain polarised light. 
parallel alignments of clays and silts often anastomose or bifurcate into several discrete zones (Fig. 29).

(c) Discrete shears within larger shear zones (Fig. 29).

(d) Shear zones with large rotated quartz grains in a clay-rich matrix (Figs. 29 and 31).

(e) Shear zones between two large grains that have moved aligning the material between (Fig. 29).

(f) Shearing of individual grains or clays, along cleavage planes in micas or a process of fracture in quartz and feldspars (Fig. 29).

Derbyshire (1981, 1983, 1984a, 1984b) and Owen and Derbyshire (1988) have described similar structures in till and similar diamictons from the Karakoram, Tian Shan, Lushan, and Great Britain.

\section{(2) Folds}

Tilting is most common but, where folds are present, they are commonly open with large wavelengths several hundred metres long often with smaller parasitic folds (Fig. 32). Large sheath folds are common in zones of constriction between large tilts (Fig. 32). Small-scale folding may produce cleavages by the rotation of clay minerals (Owen, 1988a).

\section{(3) Overconsolidation}

Most of the Jalipur tillite is overconsolidated with grain to grain contact and has a low voids ratio and consequently a high density (Fig. 33). Micas may be deposited and bent around quartz grains due to the large vertical stress (Figs. 29 and 34). Overconsolidation within tills results from overpressuring due to ice overburden or consolidation due to desiccation (Terzaghi and Peck, 1967).

Frequently, overconsolidation is differential within the till. This allows the more fluid sediment to flow and intrude into zones of already overconsolidated till and may produce zones of grain size differentiation.

\section{(4) Injection of till into fissures in the bed rock}

The overburden weight of ice and the deposition by shearing may squeeze till into fissures and joints in the base rock on which it is being de- posited and may tightly compact the till against the rock. This differs from the sandstone dykes described, in that the till would be squeezed into most joints and not just in joints of one particular orientation. There is generally a dominant set of joints into which till and glaciofluvial sands are squeezed and at the most they would only be a few centimetres in width, whereas the tectonic sandstone dykes are many decimetres wide, suggesting tectonic movements. The injection of glaciofluvial sands into bedrock solely by glacial processes has not been observed in the area.

\section{(5) Dilation joints}

Pressure release of overconsolidated till upon glacial retreat may have produced sub-horizontal dilation joints often with a weak fissility parallel to the joint (Figs. 29 and 33). Sub-vertical dilation joints may also be produced parallel to exposed vertical faces in overconsolidated tills.

(6) Pebble clusters and grain size differentiation

Pebble clusters are often present as large pebbles or cobbles associated with smaller grains or clasts indicating the sense of shear or flow within the till. The process of flow and shear may also produce grain size differentiation. However, little is known about this process.

The association of glacial facies is also important for the differentiation between glacially deformed sediments and neotectonized sediments. There is a vast range of facies ranging from ice contact fans, glaciofluvial and kame deposits to flow tills. The description of these is beyond the scope of this paper, but comprehensive descriptions are available in Owen (1988b).

Within the glacial depositional environment several phases of deposition and deformation of glacial sediments can be recognised:

(a) Deposition of till by ice: the till may be internally deformed by a variety of shears and folds. The till may be thrust on to previously deposited sediments which are frequently glaciofluvial sands.

(b) Ice may override previously deposited sediments deforming them and emplacing till into the sequence by a process of thrusting. 


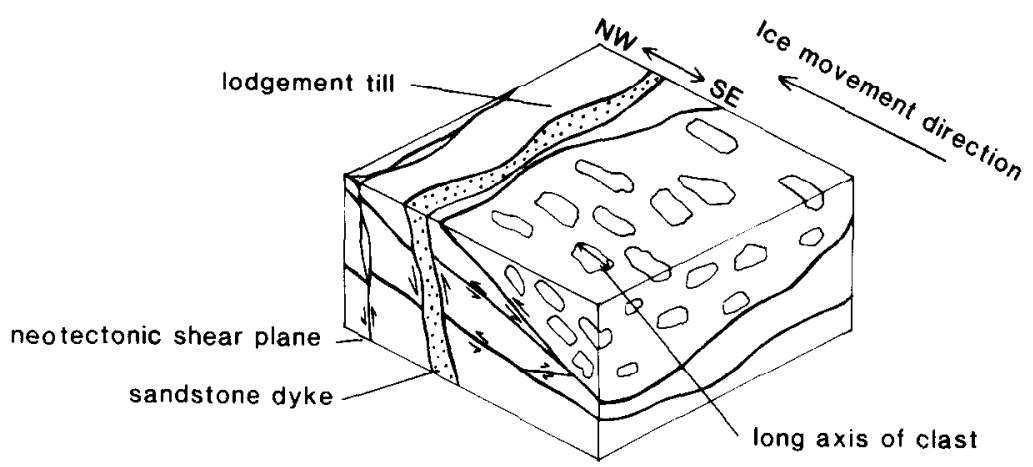

A.

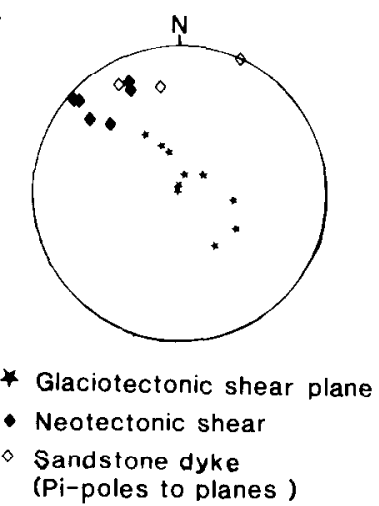

B.

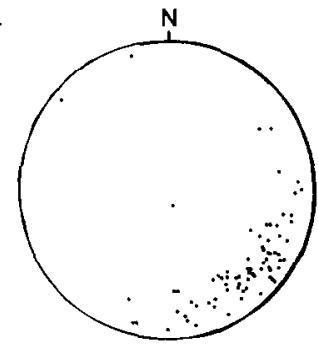

Stereonet for till clast fabric

(Plung of long axis)

Fig. 35. Block diagram summarizing the structures induced in lodgement till by glaciotectonics and neotectonics. Stereonet A: plots of shears and sandstone dykes. Stereonet B: till pebble fabric plots.

(c) Overconsolidation of tills and associated sediments may occur due to the overburden weight of the ice.

(d) Desiccation may occur upon ice retreat producing a mixture of different viscosity sediments within the till producing grain size differentiation. Desiccation also produces overconsolidation (Terzaghi and Peck, 1967).

(e) Dilation occurs after desiccation and the release of overburden pressure due to ice retreat resulting in sub-horizontal pressure release joints or sub-vertical joints on exposed vertical faces.

The previous sections have shown that there is a large variety of structures produced by neotectonic, glaciotectonic and slope related processes. Many of these structures are similar in form and taken in isolation are difficult to interpret. It is therefore necessary to examine these structures in their full context in order to assign processes to their formation and hence make valid interpretations regarding neotectonic and glacial models for an area.
An example of the distinction between shears produced by neotectonic and glaciotectonic processes

The major problem in areas such as Rakhiot is differentiating between glacial and neotectonic deformation within a sediment. Lodgement tills east of Barchala Gah provide an example of sediment sheared by both types of deformation. The orientation of the shear planes within the tills is plotted on the stereonet $\mathrm{A}$ in Fig. 35. Two populations can be recognised, a dipping at a high angle $\left(80-90^{\circ}\right)$ towards the southeast and a set dipping at a lower angle $\left(50-5^{\circ}\right)$ towards the southeast. The "sandstone dykes" described above are also present and are vertical.

Since the high-angled shears are in the same orientation as the neotectonic "sandstone dykes", it is reasonable to assign them to a neotectonic origin. To prove that the low-angle shears are glaciotectonic in origin, it must be shown that they rclate to ice movement direction. Stereonet $B$ in Fig. 35 shows the pebble fabric orientation using 

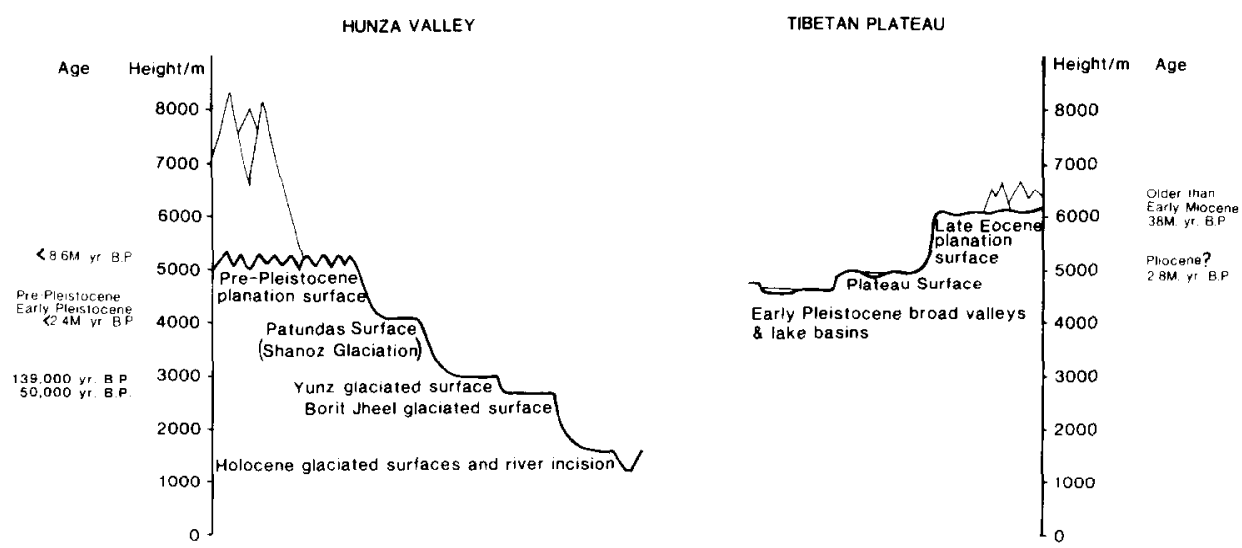

Fig. 36. Summary diagram of the planation and glacial surfaces in Hunza and on the Tibetan Plateau.

the long axis of pebble-size clasts. There is a large cluster of long-axis orientation towards the southeast, dipping $10-20^{\circ}$, which indicates an ice movement direction towards the northwest (Holmes, 1941). Thus the ice movement direction is consistent with the low-angled shears dipping towards the southeast, being glaciotectonic in origin, and the NW-dipping shears being back shears related to the same movement.

\section{Discussion and conclusion}

The Karakoram mountains and Nanga Parbat Himalaya are still rising at an average rate in excess of $2 \mathrm{~mm} / \mathrm{yr}$ (cf. Table 1). Only two active faults, the Rakhiot fault and a recently discovered fault in the Misgar valley, have been recognised in the Pakistan Karakoram, the latter being inaccessible. The Lichar thrust is a neotectonic thrust along the Rakhiot fault zone, with a displacement of at least $300 \mathrm{~m}$ thrusting Nanga Parbat gneiss over glaciofluvial sediments, which were deposited during the Borit Jheel glaciation at about 65,000 yrs B.P. This gives an average displacement of about $4 \mathrm{~mm} / \mathrm{yr}$. However, this is not enough to account for the $2 \mathrm{~mm}$ vertical uplift per year in the Karakoram Mountains. It is likely that uplift is accommodated by gross doming of the Pakistan Karakoram with the greatest uplift rates concentrated around Nanga Parbat of which the Lichar thrust is a neotectonic expression. This model is supported by Zeitler's (1985) fission-track ages which increase away from Nanga Parbat sug- gesting greater rates of uplift in the Nanga Parbat area.

Nakata (1982a,b) and Nakata et al. (1984) argue for a similar situation in the high Nepal Himalaya, where they find no active faults relating to Himalayan uplift except a few bordering the southern fringe of the Siwalik Hills. Nakata et al. (1984) suggests that the upheaval of the Himalaya due to the convergence between the Indian and Asian plates was associated with an extremely low-angled thrust which has now ceased to move. Strahler and Strahler (1978) and Matsuda (1983) emphasised that long wave and long term warping is very important in the formation of primary topographic features such as large mountain ranges. Iwata (1987) also stressed that the present uplift of the Himalaya may be due to warping rather than to vertical block movement. Chinese workers ( $\mathrm{Li}$ Jijun et al., 1979) recognised three major phases which produced two extensive planation surfaces in Tibet (Fig. 36). The lower of these is at $4500-5000 \mathrm{~m}$ above sea level yielding a warm tropical Hipparion fauna. The upper planation surface is above $6000 \mathrm{~m}$ and is probably of Eocene age. Paffen et al. (1956) recognised a "pre-Pleistocene relief" above $4000 \mathrm{~m}$ in the Hunza valley which was confirmed by Derbyshire et al. (1984) to be at a height of 4100-4200 m. They called this the "Patundas Surface". A higher surface above $5200 \mathrm{~m}$ was also recogniscd. Derbyshire et al. (1984) concluded that these surfaces were younger than the Karakoram granodiorite dated at 8.6 Ma B.P. (Desio et al., 1964) and 
suggested an age of early Pleistocene for the Patundas surface and a Pliocene age for the higher surface. This supports large-scale warping and punctuated uplift of High Asia. However, Fort (1987) and Fort et al. (1982) argue for neotectonic activity in the Pokhara basin and ThakkholaMustang graben. These may be considered as local concentrations of stress in the upward warping Himalaya.

NNW-SSE and ENE-WSW orthogonal sets of lineaments in the Pakistan Karakoram do not have orientations that can be explained by hinterland extension produced by crustal spreading (Coward et al., 1987) nor do they relate to Tapponnier and Molnar's (1976) structures predicted by slipline field theory for the collision of the Indian plate as a rigid indenter into the Asian-Kohistan plate. Rather, they relate to a primeval drainage system possibly controlled by major folds within the Kohistan complex which should have conjugate weakness or joints oriented NNW-SSE and ENE-WSW in relation to the ESE axial traces of the folds.

The uplift of the Karakoram probably took place as gentle warping with several areas of localised deformation. Palaeomagnetic studies (Molnar and Tapponnier, 1975) show that India has been moving into Asia at a rate of over $4 \mathrm{~cm} / \mathrm{yr}$ since 40 Ma B.P. Most of this movement must have been taken up in the foreland of the Himalayas by foreland propagating thrusts. This is supported by Coward and Butler (1985) and by dating of the loess surfaces on the Potwar Plateau (H. Rendell, per. commun., 1988). Movement may also be accommodated by large strike-slip faults on the northern margin of the Karakoram (e.g. Karakoram fault) and in the Kun Lun (Fig. 1), Molnar et al. (1987) suggests that rates of slip along the Altyn-Tagh fault may be as high as $30 \pm 20 \mathrm{~mm} / \mathrm{yr}$ and may alone account for $10-20 \%$ of India's convergence with Eurasia.

The Rakhiot area has undergone neotectonic deformation and major valley glaciation during the Yunz and Borit Jheel glaciations. The sedimentary record is complex with folding and thrusting sediments relating to both neotectonics and glacial deformation processes. Glaciofluvial sands have been deformed due to glaciers overrid- ing them and emplacing tills into the sequence by thrusting. The tills themselves have thrusts and shears within them and are overconsolidated, they are essentially tillites.

Furthermore, glaciofluvial sands have been neotectonically deformed by a major shear zone, the Lichar shear zone, with an oblique strike-slip movement related to the deformation of the Nanga Parbat syntaxis. The glaciofluvial sediments have been overthrust by Nanga Parbat gneiss, folded, inverted and sheared. Hot springs are present probably relating to the MMT. In the historical record (1841: Mason, 1929) a major earthquake initiated the collapse of the Lichar Spur which blocked the Indus. Microseismic work supports active tectonics in this region (Khurshid et al., 1984).

Debris-slide deposits are common and their movement is confined to discrete shear planes, which may be mistaken for neotectonic structures.

It is important when producing a neotectonic model for active high mountain belts, such as the Karakoram and Nanga Parbat Himalaya, to consider the different processes that deform sediments and to be able to recognise their structures.

\section{Acknowledgements}

Sue Page for patiently typing this manuscript and to the people of the northern areas of Pakis$\tan$ for their hospitality, especially Mr. Lathif during my stay at the Mir of Naga's Palace. This research was funded by the NERC grant No. GT4/85/GS/46.

\section{References}

Ambruster, J., Seeber, L. and Jacob, K.H,, 1978. The northwestern termination of the Himalayan Mountain Front: active tectonics from microearthquakes. J. Geophys. Res., 83: 269-282.

Butler, R.W.H. and Prior, D.J., 1988. Tectonic controls on uplift of the Nanga Parbat Massif, Pakistan Himalaya. Nature, 333: 247-250.

Burg, J.P. and Chen, G.M., 1984. Tectonics and structural zonation of southern Tibet, China. Nature, 311: 219-223.

Coward, M.P. and Butler, R.W.H., 1985. Thrust tectonics and the deep structure of Pakistan Himalayas. Geology, 13: 20-47.

Coward, M.P., Jan, M.Q., Rex, D., Tarney, T., Thirlwall, M. 
and Windley, B.F., 1982a. Structural evolution of a crustal section in the western Himalaya. Nature, 295: 22.

Coward, M.P., Jan, M.Q., Rex, D., Tarney, T., Thirlwall, M. and Windley, B.F., 1982b. Geotectonic framework of the Himalaya of North Pakistan. J. Geol. Soc. London, 139: 299-308.

Coward, M.P., Pudsey, C., Rex, D. and Asif Khan, M., 1986. Collision tectonics in the NW Himalayas. In: M.P. Coward and A.C. Ries (Editors), Collision tectonics. Spec. Publ., Geol. Soc. London, 19: 203-219.

Coward, M.P., Butler, W.H., Khan, M.A. and Knipe, R.J., 1987. The tectonic history of Kohistan and its implications for Himalayan structure J. Geol. Soc London, 144: 377-391.

Curray, J.R. and Moore, D.G., 1971. Growth of the Bengal deep-sea fan and denudation in the Himalayas. Geol. Soc. Am. Bull., 82: 563-572.

Derbyshire, E., 1981. Glacier regime and glacial sediment facies: a hypothetical framework, for the Qinghai-Xizong Plateau. In: Proceedings of Symposium on Qinghai-Xizong (Tibet) Plateau, Beijing China. Vol. 2. Geological and Ecological Studies of Qinghai-Xizang Plateau, Science Press, Beijing, pp. 1649-1656

Derbyshire, E., 1983. The Lushan Dilemma: Pleistocene glaciation south of the Chang Jiang (Yangtze River). Z. Geomorphol., 27: 445-471.

Derbyshire, E., 1984a. Sedimentological analysis of glacial and proglacial debris: a framework for the study of Karakorum glaciers. K.J. Miller (Editor), In: International Karakorum Project, Vol. 1. Cambridge University Press, Cambridge, pp. 347-364.

Derbyshire, E., 1984b. Till properties and glacier regime in parts of High Asia: Karakorum and Tian Shan. In: The Evolution of the East Asian Environment, Vol. 1. Geology and Palaeoclimatology. Centre of Asian Studies, University of Hong Kong, pp. 84-110.

Derbyshire, E., Li Jijun, Perrott, F.A., Xu Shuying and Waters, R.S., 1984. Quaternary glacial history of the Hunza Valley, Karakorum mountains, Pakistan. In: K.J. Miller (Editor), International Karakorum Project, Vol. 2. Cambridge University Press, Cambridge, pp. 456-495.

Desio, A., Tongiorgi, E. and Ferrara, G., 1964. On the geological age of some granites of the Karakoram, Hindu Kush and Badakhstan, Central Asia. Proc. 22nd Int. Geol. Congr., New Delhi, 11: 479-496.

Drew F., 1875 reprinted 1980. The Jummoo and Kashmir Territories. Indus Publ., Karakachi, 568 pp.

Ferguson, R.J., 1984. Sediment load of the Hunza River. In: K. Miller, (Editor), International Karakorum Project, Vol. 2. Cambridge University Press, Cambridge, pp. 374-382.

Fort, M., 1987. Sporadic morphogenesis in a continental subduction setting: An example from the Annapuna Range, Nepal Himalaya, Z. Geomorphol. N.F., Supp., 63: 9-36.

Fort, M., Freytet, P., and Colchen, M., 1982. Structural and sedimentological evolution of the Thakkhola-Mustang graben (Nepal Himalayas), $Z$. Geomorphol., Suppl., 42: $75-98$.

Gansser, A., 1980. The division between Himalaya and Karakorum, Geol. Bull. Univ. Peshawar, Pakistan, 13: 9-22.

Gornitz, V. and Seeber, L., 1981. Morphotectonic analysis of the Hazara arc region of the Himalayas, North Pakistan and Northwest India. Tectonophysics, 74: 263-282.

Henderson, W., 1859. Memorandum on the nature and effects of the flooding of the Indus on 10th August 1858 as ascertained at Attock and its neighbourhood. J. Asiat. Soc. Bengal, 28: 199-219.

Holmes, C.D., 1941. Till fabric, Geol. Soc. Am. Bull., 52: $1299-1354$

Iwata, S.T., 1987. Mode and rate of uplift of the central Nepal Himalaya. Z. Geomorphol., N.F., 63: 37-49.

Iwata, S., Sharma, T. and Yamanaka, H., 1984. A preliminary report on geomorphology of Central Nepal and Himalayan uplift. I. Nepal Geol. Soc. 4 (Special Issue): 141-149.

Khurshid, M., Yielding, G., Ahmad, S., Davidson, I., Jackson, J.A., King, G.C.P. and Lin Ban Zuo, 1984. The seismicity of northernmost Pakistan. Tectonophysics, 109: 209-226.

Lawrence, R.D. and Shroder, J.F., 1984. Active fault northwest of Nanga Parbat. In: Volume of Abstracts; First Pakistan Geological Congress, Lahore. Institute of Geology, Punjab University, Lahore, Pakistan.

Li Jijun, Wen Shixuan, Zhong Qingsong, Wong Fubao, Zheng Benxing and Li Bingyuan, 1979. A discussion on the period, amplitude and type of the uplift of the Qinghai-Xizang Plateau, Sci. Sin. 22: 1314-1327.

Li Jijun, Derbyshire, E. and Xu Shying, 1984. Glacial and paraglacial sediments of the Hunza Valley north-west Karakorum, Pakistan: a preliminary analysis. In: K.J. Miller (Editor), International Karakorum Project, Vol. 2. Cambridge University Press, Cambridge, pp. 496-535.

Lyong-Caen, H. and Molnar, P., 1983. Constraints on the structure of the Himalayas for an analysis. Gravity anomalies in a flexual model of the lithosphere. J. Geophys. Res., 88: 81718191.

Mason, K., 1929. Indus floods and Shyok glaciers, Himalayan, J., 1: 10-29.

Matsuda, T., 1983. Magnitude and frequency of crustal movements. Trans. Japanese Geomorphol. Union, 4: 151-165.

Mehta, P.I.C., 1980. Tectonic significance of the young mineral dates and rates of cooling and uplift in the Himalayas. Tectonophysics. 62: 205-217.

Misch, P., 1935. Eingefalteter junger Sandstein im NordwestHimalaya und sein Gefüge. In: Festschrift zum 60 Geburtstag von Hans Stille. Enke. Suttgart; pp. 259-276.

Molnar, P. and Tapponnier, P., 1975. Cenozone tectonics of Asia; effects of a continental collision. Science, 189: 419.

Molnar, P., Burchfiel, B.C., Liang K'uangyi and Zhao Ziyun, 1987. Geomorphic evidence for active faulting in the Altyn Tagh and northern Tibet and qualitative estimates of its contribution to the convergence of India and Eurasia, Geology, 15: 249-253 
Morley, C.K., 1986. A classification of thrust fronts. Am. Assoc. Pet. Geol. Bull., 70: 12-25.

Nakata, T., 1982a. A photogrammetic study on active faults in the Nepal Himalayas, J. Nepal Geol., Soc., 2 (Special Issue): 67-80.

Nakata, T., 1982b. Active faults along the foot-hills of the Darjeeling Himalayas. In: The Region: its cultural and physical aspects, Fukutake, Tokyo, pp. 448163.

Nakata, T., Iwata, S., Yamanaka, H., Yagi, H. and Maemoku, H., 1984. Tectonic landforms of several active faults in the western Nepal Himalayas, J. Nepal Geol. Soc., 4 (Special Issue) 177-199.

Obbard, J., 1860. On the translation of waves of water in relation to the great flood of the Indus in 1858. J. Asiat. Soc. Bengal, 29: 266-274.

Olson, T., 1982. Jalipur Sequence. MSc. thesis. Dartmouth College (unpublished).

Owen, L.A., 1987. Wet-scdiment deformation in Quaternary and Recent river terraces in the Karakoram Mountain. Himalayan Workshop, CNRS, Nancy, abstr.

Owen, L.A., 1988a. Wet-sediment deformation of Quaternary and recent sediments in the Skardu Basin, Karakoram Mountains, Pakistan. In: D. Croot (Editor), Glaciotectonics. Balkema, Rotterdam, pp. 123-147.

Owen, L.A., 1988b. Terraces, uplift and climate, Karakoram Mountains, Northern Pakistan. PhD thesis, University of Leicester, Leicester 399 pp. (unpublished).

Owen, L.A. and Derbyshire, E., 1988. Glacially deformed diamictons in the Karakoram Mountains, Northern Pakistan. In: D. Croot (Editor), Glaciotectonics. Balkema, Rotterdam, pp. 149-176.

Paffen, K.H., Pillowizer, W. and Schneider, H.J., 1956. Forschungen in Hunza-Karakorum. Erdkunde. 10: 1-33.
Petterson, M.G. and Windley, B.C., 1985. Rb-Sr dating of the Kohistan arc-batholith in the Trans-Himalayan of $\mathrm{N}$. Pakistan, and its tectonic implications. Earth Planet. Sci. Lett., 74: 45-57.

Scheiddegger, A.E. and Ai, N.S., 1986. Tectonic processes and geomorphical design. Tectonophysics, 126: 285-300.

Seeber, L. and Gornitz, V., 1983. River profiles along the Himalayan arc as indicators of active tectonics. Tectonophysics. 92: 335-367.

Shaw, R.B., 1871 (reprinted 1984). Visits to High Tartary, Yarkard and Kashgar. Oxford University Press, Hong Kong, 432 pp.

Strahler, A.N. and Strahler, A.H., 1978, Modern Physical Geography. Wiley, New York, N.Y., 502 pp.

Tahirkheli, R.A.K. and Jan, M.Q., 1979. Geology of Kohistan, Karakorum Himalaya, northern Pakistan. Geol. Bull. Univ. Peshawar, Pakistan, 11 (Special Issue): 1-30.

Tapponnier, P. and Molnar, P., 1976. Slip-line theory and large-scale continental tectonics. Nature, 264: 319-324.

Tapponnier, P., Mattauer, M., Proust, F. and Parsaigneu, C., 1981. Mesozoic Ophiolites, sutures and large scale tectonic movements in Afghanistan. Earth Planet. Sci. Lett., 52: 355-371

Terzaghi, K. and Peck, R.B., 1967. Soil Mechanics in Engineering Practice. Wiley, London, $729 \mathrm{pp}$.

Wadia, D.N., 1975. Geology of India. Tata McGraw-Hill, New Delhi.

Yiclding, G., Ahmad, S., Davison, I., Jackson, J.A., Khattok, R., Khurshid, A., King, G.C.P. and Zuo, L.B., 1984. A microearthquake survey in the Karakoram. In: K. Miller (Editor), Proc. Int. Karakoram Proj., pp. 149-169.

Zeitler, P.K. 1985. Cooling history of the N.W. Himalaya, Pakistan. Tectonics, 4: 127-151. 